What's wrong with economics

Por Benjamin Ward. McMillan, 1972. tema econômico. Tomemos o caso dos modelos econométricos tão em voga nas últimas décadas. Após 20 anos de esforços e vultosas somas destinadas ao aperfeiçoamento destes, reconhece-se que as previsões que conseguem fazer não são melhores que "chutes" dados por conhecedores do ramo. O mesmo pode ser dito com relação à economia matemática que até hoje só conseguiu discursar sobre o óbvio e o irrelevante.

Por que tal revolução formal na economia teria levado a resultados tão desapontadores? 0 que há de errado com a economia? Benjamin Ward acredita que o fracasso da economia neoclássica estaria intimamente ligado à estreita associação existente entre a visão neoclássica da economia com - sistema político dito "liberal".

Tal associação em termos práticos vetaria a análise de alternativas econômicas radicalmente diferentes das existentes. Também devido a uma pretensa tentativa de não se envolver em questões que impliquem julgamentos de valor, a grande maioria dos problemas econômicos que nos afligem e que estariam dentro de um contexto político-social mais amplo seria m cuidadosamente evitados. As únicas análises que, nessa visão de ciência positiva, poderiam ser feitas seriam aquelas relativas a ajustamentos marginais, isto é, insignificantes, do sistema. E nesta análise da insignificância, a economia neoclás. sica tem se dedicado com o corpo e a alma nas últimas décadas.

Quanto à alternativa marxista de análise econômica, esta não padeceria, segundo Ward, do problema da irrelevância que aflige à economia neoclássica. Os problemas abordados são relevantes, não existe a tendência de se evitar a análise de problema que envolvam juizos de valor sob a alegação de que pretensamente este tipo de análise comprometeria o nível científico do trabaIho, e o instrumental à disposição dos marxistas é suficientemente poderoso para que possam ter uma visão adequada do funcionamento do sistema económico. $O$ problema dos marxistas, segundo o autor, é que em vez de desenvolverem suas teorias através de um aprofundamento, de um refinamento de seu instrumental de análise, estes têm-se dedicado muito mais ao proselitismo político. Embora tal opção possa render juros em termos político-partidários, em termos do desenvolvimento da ciência econômica tem sido muito pouco produtiva.

Que alternativas teríamos à nossa frente se quiséssemos desenvolver uma ciência econômica relevante para os problemas que enfrentamos hoje em dia? Ward apresenta suas sugestōes de ordem metodológica para que a economia possa sair do marasmo em que se encontra. Embora talvez não concordemos inteiramente com tudo o que propõe, as sugestões básicas, de que o formalismo e o medo de fazer análises que envolvam julgamentos básicos éticos devam ser abandonados, aceitaríamos de bom grado.

Não cremos que se trate de um livro que irá agradar a todos os leitores, especialmente àqueles que ainda se encontram na fase de deslumbramento face ao formalismo atingido pela economia. Entretanto, é uma obra que deveria ser lida por todos que se dedicam à análise econômica, quer concordem ou não com o autor, devido à importância dos problemas metodológicos levantados e a atenção que o autor nos exige para vários pressupostos implicitamente aceitos por quase todos na área de economia e que talvez estejam dificultando o desenvolvimento de uma visão adequada do homem em sua atividade econômica.

Robert. N. V. C. Nicol matemática ou com a econom cação que se atingiu nessas áreas nos últimos anos. Entretanto, a revolução nos insumos na economia não foi acompanhada por uma melhoria no produto final; em outras palavras, a sofisticação formal atingida na teoria econômica não levou a nenhum aumento perceptivel em nossa compreensão do funcionamento do sis- 


\section{Introdução ao esłudo da História do Brasil}

Por Américo Jacobina Lacombe. São Paulo, Comp. Editora Nacional, 1974. 208p. (Col. Brasiliana, n. 350)

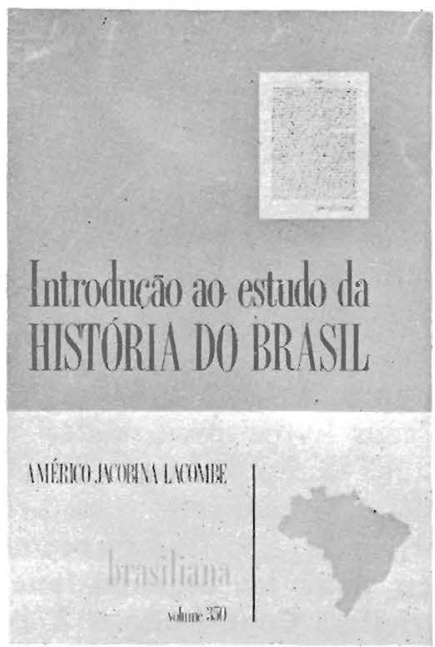

A inexistência de guias e de boas bibliografias sobre o Brasil é uma realidade negativa, que prejudica - conhecimento de nossos problemas e dificulta sobremaneira a abordagem de nossa história. Assim, a maior parte dos estudiosos ou iniciantes defrontam-se com empecilhos de difícil superação, o que os leva, comumenie, a desconhecer o material ou os instrumentos existentes. O resultado é um contínuo esforço individual, em que as conclusões se apresentam grandemente ímpares, porque boa parte dos trabalhos se canaliza para o levantamento do material existente.

As biografias gerais e particulares são parcas e, na maioria, esgotadas. Com tiragens restritas e publicadas em revistas provincianas de difícil acesso ou, em outras vezes, em livros de editoras efêmeras, elas são na maior parte das vezes desconhecidas. É caso raro uma publicação dessas merecer reedição: a não ser, por exemplo o livro de um Nelson Werneck Sodré 10 que se deve ler para conhecer ○ Brasil. 4. ed., Civilização Brasileira, 1973.) ou o de Sacramento Blake - Dicionário bibliográfico brasileiro, que foi reeditado pelo Governo fede- ral, após 70 anos da edição original.

O livro de Américo Jacobina Lacombe não é uma bibliografia, nem pretende ser um guia crítico de nosșa história. É simplesmente uma introdução à nossa história, isto é, um levantamento das fontes, centros de atividades e de ensino que possam ser utilizados por qualquer um de nós. Sem ser ambicioso e negativo, ele é uma enumeração precisa sobre vários aspectos ligados ao estudo e compreensão do pensamento histórico nacional.

A obra divide-se em sete partes e uma conclusão, assim descritas: Fontes históricas, Setores da história, Disciplinas auxiliares, Elaboração da história do Brasil, Centros de atividade histórica, Ensino de história e historiografia brasileira.

$\mathrm{Na}$ parte sobre Fontes históricas, o autor começa explicando a intenção primeira do professor ou orientador: "O sentimento inicial que o professor de História deve despertar aos alunos é o de respeito pela matéria, considerada como ciência. Nada poderá concorrer mais para isso do que ir deśfazendo a noção de que a história não passa de um relato que lhes é imposto em nome de uma sociedade em que eles não incorporaram. Seria de toda vantagem que eles tivessem, logo que possível, a noção da complexidade da elaboração da história, da crítica objetiva e da participação que poderão trazer à história. Para isso nada melhor do que entrarem logo em contato com alguns textos." Assim o testemunho pessoal (cartas, diários etc.) é parte integrante que se denomina documento ("exame dos testemunhos reduzido a escrito"), "material de trabalho por excelência"; por sua vez, o estudo da história local perfaz-se com a heurística, "coordenação das fontes" em geral. E por isto que o autor enumera as possíveis fontes locais e gerais, indo por exemplo do Diário de André Rebouças aos conteúdos de Torre de Tombo, Arquivo Histórico Ultramarino, Biblioteca Nacional e outros.

$\mathrm{Na}$ parte relativa aos Setores da história estuda a periodização, a história regional, a biografia, as memórias, correspondência, diários e a genealogia. Em cada um destes itens apresenta conceitos e dá uma bibliografia brasileira. O mesmo faz com as Disciplinas auxiliares, quando fala da paleografia, filologia, diplomática, etc.

Apesar de tratarem de problemas distintos, os capítulos 4 e 7 completam-se: Elaboração da história do Brasil e Historiografia brasileira.

Ao falar dos primeiros cronistas, o autor mostra a sua valiosa contribuição dizendo que, a "História Brasileira foi elaborada lentamente, através dos esforços contínuos de escritores, visitantes, cronistas e entidades coletivas, tanto brasileiras quanto portuguesas". Particularmente existiram cronistas oficiais entre nós, mas por várias razões os seus trabalhos não tiveram importância primordial; cabem aos cronistas particulares - leigos e jesuítas - uma ação mais duradoura, fato exemplificado pelas obras de Pero de Magalhães Gandavo, Fernão Cardim, Gabriel Soares de Souza, Rocha Pita, etc.

Porém, é a partir do século XIX que se inicia o verdadeiro estudo da história, principalmente com Adolfo Varnhagen e sua História geral do Brasil. Varnhagen anuncia $\circ$ grande momento de nossa historiografia, mas é antecedido por autores que não podem ser esquecidos, como os casos de Robert Southey (História do Brasil), Monsenhor Pizarro (Memórias históricas do Rio de Janeiro), Visconde de São Leopoldo (Anaes da província de São Pedro), etc. São Varnhagen e seus discípulos, entretanto, que representam a corrente mais valiosa para o conhecimento de nossa realidade. Capistrano de Abreu é o grande momento de continuidade desta escola e, através de seus livros e discípulos, tivemos a elaboração de novas obras básicas (Afonso de Taunay, Helio Viana).

Nos capítulos sobre Ensino de história e Centros de atividades históricas temos o levantamento preciso das atividades privadas e públicas que contribuiram para a fixação do pensamento históri- 
co: o autor mostra os papéis da Academia Real de História (1720), da Academia dos Esquecidos (1724), os Institutos Histórico e Biográfico Brasileiro (1838), da Academia Brasileira de Letras (1896) e vai até os atuais Congressos de História e Colóquios Luso-brasileiros. Das atividades privadas ele passa ao ensino público, mostrando a ação do Estado durante a Colônia, Império e República. Os maiores apresentados mostram a continuidade de ambos, apesar do caráter e finalidade distintas de cada uma delas, no espaço e no tempo.

Assim, a obra de Américo Jacobina Lacombe é excelente guia para os iniciantes e os estudiosos da história do Brasil. Além de apresentar caminhos seguros de serem percorridos, a obra é também uma introdução bibliográfica geral e particular da nossa história.

\section{Relations industrielles}

Por Dimitri Weiss. 1. ed., Paris, Sirey, 1973. 334 p., formato $18 \times 22,5 \mathrm{~cm}$ brochura.

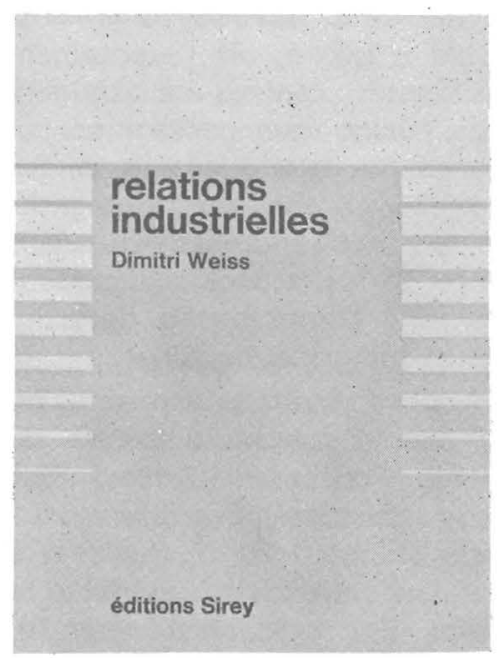

O tema Relações industriais, tratado pelo Prof. Dimitri Weiss, tem os países do Mercado Comum Europeu por quadro amplo de referência, com ênfase na experiência francesa e citações em relação aos Estados Unidos e Japão.

O autor divide o livro em quatro partes: Relações industriais, Conflitos na sociedade industrial, Negociações coletivas e Partners sociais, Transnacionalização das relações industriais.

$\mathrm{Na}$ primeira parte, após um breve histórico das diferentes conotações atribuídas à expressão "relações industriais", termina por optar por seu caráter interdisciplinar, envolvendo c i ências do comportamento, administração, economia e direito do trabalho.

Em uma abordagem teóricoprática, o autor desenvolve as duas partes subseqüentes, analisando as diferentes modalidades de conflitos e negociações coletivas, no contexto multidisciplinar em que se propôs desenvolver o tema.

A quarta parte trata dos diversos mecanismos de participação, co-participação, co-administração e co-surveillance desenvolvidos pelos países do Mercado Comum Europeu e o papel de transnacio- nalização exercido pelas empresas multinacionais.

Este último tema também é utilizado na conclusão do livro, para colocar a problemática das empresas multinacionais na elaboração e aplicação de políticas de relações industriais a níveis nacionais.

O livro contém amplas referências bibliográficas e anexos de legislação. A consulta por assuntos é facilitada por um índice alfabético analítico. Pela amplitude do tema e seu enfoque multidisciplinar, o livro é indicado para estudos de sistemas comparados.

O autor considera útil a leitura dos seus livros precedentes para melhor compreensão do livro atual: Communication et presse d'entreprise, 1971; La communication dans les organizations industrielles; Contributions à l'étude de la presse d'entreprise et essai de bibliographie, 1971, ambos da Editora Sirey, e Les relations du travail: employeurs, personnell, syndicats, Etat. 1972, da Editora Dunod.

Ofélia de Lana Primus 


\section{Tomada de decisões pelo executivo}

Por Manley Howe Jories. São Pau1o, Editora Atlas, 1973. $638 \mathrm{p}$.

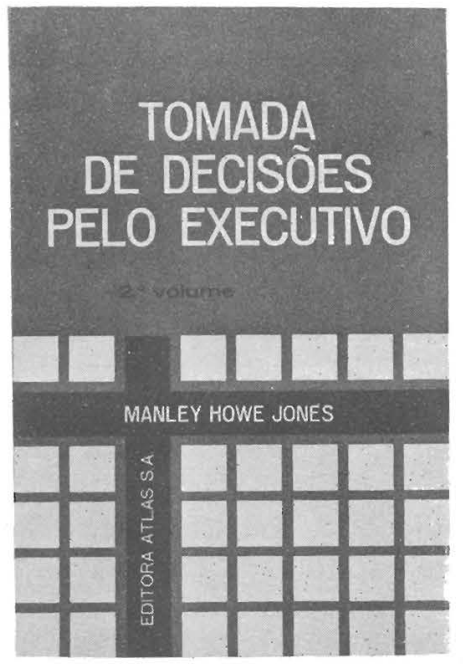

A tomada de decisão é o fato mais comum na vida administrativa de um executivo. Para sobreviver as organizações precisam decidir rapidamente e no momento certo.

Jones procura academicamente demonstrar três tipos de metas que devemos ter em mente quando procuramos decidir: metas fundamentais, intermediárias e imediatas. As metas fundamentais são aquelas que, embora sejam as últimas a serem alcançadas, provocam muitas de nossa decisões. Em outras palavras, as metas fundamentais são o nosso objetivo final de um processo decisório. O autór justifica a necessidade da existência de metas fundamentais dizendo que, para tomar decisões, os homens (as empresas) têm que selecionar os objetivos que possuam real significado e têm que converter vagas imagens que flutuam em suas mentes em quadros explícitos capazes de serem enunciados em palavras. Não somente em palavras, completaríamos, mas em ação. Um grande problema que muitas organizações encontram é a existência de um razoável gap entre $\circ$ que as palavras estabeleceram como objetivos e ao que a ação conduziu a organização. Aqui podemos constatar a existência de metas fundamentais filiadas ao quadro irreal, mas que foram convincentemente $\mathrm{co}$ locadas em palavras por este ou aquele executivo. Em síntese, as metas fundamentais devem estar calcadas em fatos possíveis de serem alcançados quando se passa da palavra à ação.

As metas intermediárias existem em função das fundamentais. Elas são, na realidade, o meio de se chegar às metas fundamentais. Essas metas virão a se constituir no que habitualmente chamamos de processo decisório.

As metas imediatas são semeIhantes ao escalonamento feito com relação às metas fundamentais e intermediárias. O grande perigo é que as metas imediatas podem mudar o curso de ação imposto por metas intermediárias e metas fundamentais. Neste caso, o ajuste das metas fundamentais deve e tem que ser feito na fase intermediária.

O aspecto criativo é também apontado pelo autor. Podemos considerar que o trabalho do executivo é sobretudo criativo ou, pelo menos, deveria ser. Na realidade, é função do executivo buscar na fonte os problemas or. ganizacionais e procurar as várias alternativas de solução. Para que $\circ$ processo criativo seja levado a efeito, diz Jones, é preciso - cumprimento de seis etapas. Esta pode ser uma sugestão perigosa, mas, afinal de contas, serve-nos como um roteiro que pode ou não ser seguido e serve ao autor para o estabelecimento de um outro subsistema conceitual, qual seja o uso das premissas na tomada de decisão.

É importante saber identificar como as pessoas na organização estabelecem as suas metas. Apenas para colocar esta inquietação, o autor faz uma generalização, dizendo que as necessidades primordiais dos homens são de ordem psicológica e biológica. Se - indivíduo consegue descobrir uma forma de preencher as suas necessidades, é crível que em seguida tente alcançar um segundo degrau, qual seja, a preservação de sua vida, propriedade e posição. Mais tarde o indivíduo busca as necessidades de seu ego ser independente, ganhar reputação, etc. A dificuldade está em se definirem metas comumente fixadas pelos indivíduos, e, note-se, as metas dos indivíduos devem em princípio ser compatíveis com as estabelecidas pela organização. Para se identificar as aspirações dos indivíduos, uma sugestão: saber oụvir. Esse é um dos métodos mais eficazes e, não muito freqüentemente, posto em prática.

A aceitação de decisão, que é a segunda parte do livro, está relacionada diretamente com a ocorrência de resistências às mudanças dentro da organização. Dependendo da decisão, ela poderá: a) ser aceita; b) ser considerada indiferente, levando os indivíduos na organização à apatia e conseqüente perda de motivação; c) resistência passiva, que é, seguramente, a pior de todas as resistências, já que é difícil a sua localização; d) resistência ativa, que pode conduzir qualquer decisão aos caminhos do erro e da sabotagem deliberada. Por isso o processo decisório deve estar condicionado à participação efetiva das pessoas envolvidas mesmo que em caráter circunstancial. Ao executivo cabe esse papel: o de demonstrar o porquê de uma decisão a ser tomada e tentar oferecer subsídios para que esta decisão seja assimilada pelos envolvidos. Concordamos que esta seja a parte mais difícil de um processo decisório, tanto é que o autor dedica mais de $1 / 3$ de seu livro à problemática da aceitação de decisões.

Luís César Gonçalves de Araújo 
Café e ferrovias: a evolução ferroviária de São Paulo e - desenvolvimento da culfura cafeeira

Por Odilon Nogueira de Matos. São Paulo, Alfa-Omega, Sociologia e Política, 1974. 135 p.

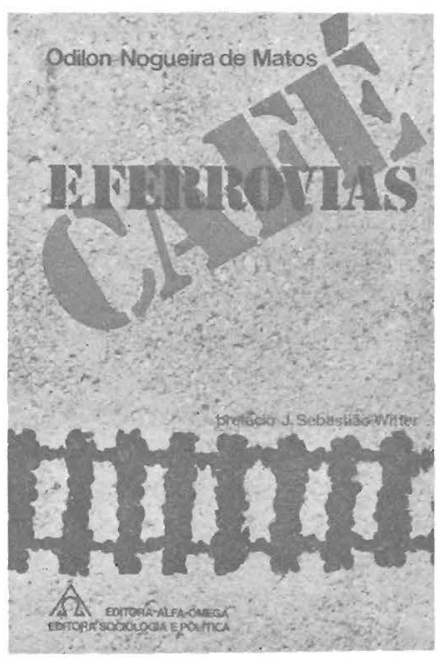

Este livrinho-caro, com erros de diagramação e revisão e pessima. mente impresso, contém um im. portante texto de análise histórica, elaborado por um dos mais cuidadosos e profundos conhecedores do processo de desenvolvimento paulista do século XIX.
O Prof. Odilon Nogueira de Matos, autor de alguns trabalhos notáveis como, por exemplo, a clássica análise sobre $A$ cidade de São Paulo no século $X I X$ publicada na Revista de História, vem, de novo, oferecer-nos uma outra análise esclarecedora e, em alguns aspectos, muito sugestiva sobre a relação entre a evolução ferroviária e o desenvolvimento da cul. tura cafeeira em São Paulo.

Ao contrário. da hipótese de Richard Graham, apresentada em Grã-Bretanha' e o início da moder nização no Brasil (São Paulo, Editora Brasiliense, 1973), que argumenta sobre a importância do capital e da tecnologia inglesa para a evolução ferroviária de São Paulo, Odilon Nogueira de Matos demonstra que tal processo dependeu fundamentalmente de incentivos estatais e do capital da burguesia cafeeira. Demonstra, também, de que forma o estado imperial e especialmente o provincial for am crescentemente influenciado e composto por elementos da burguesia cafeeira, "galardoada com títulos de nobreza", de forma que não se constituía em algo distinto e sim numa organização que representava cada vez mais os interesses dessa mesma burguesia.

Mas a importância do trabalho de Odilon Nogueira de Matos não termina aqui, pois além de dirimir algumas dúvidas fundamentais, sugere um conjunto de problemas que ainda requerem investigações para que se meIhor compreenda o desenvolvimento socioeconômico de São Paulo, a partir da segunda metade do século XIX. Assim, à página 44 , quando analisa as transformações ocorridas nas diversas regiões do estado, devidas à expansão cafeeira e à evolução ferroviária, sugere que "os movi. mentos de deslocação interna de populações constitui um fascinante capítulo da história de São Paulo, à espera ainda de quem se disponha a estudá-los". De fato, até agora os estudiosos preocuparam-se fundamentalmente com a imigração italiana para São Paulo, pois consideram que tal movimento populacional constitui um nódulo histórico importante para a compreensão da passagem trabalho escravo - colonato trabalho livre no Brasil. Mas observemos por um momento os dados populacionais que nos fornece Odilon Nogueira de Matos:

Distribuição da população por regiōes do Estado de São Paulo em 1846, 1854, 1886,1920 e 1935

\begin{tabular}{|c|c|c|c|c|c|c|c|c|c|c|}
\hline \multirow{2}{*}{ Regiões } & \multicolumn{2}{|l|}{1846} & \multicolumn{2}{|l|}{1854} & \multicolumn{2}{|l|}{1886} & \multicolumn{2}{|l|}{1920} & \multicolumn{2}{|l|}{1935} \\
\hline & População & $\%$ & População & $\%$ & População & $\%$ & População & $\%$ & População & $\%$ \\
\hline Norte & 105679 & 45,65 & 146055 & 38,00 & 338533 & 32,66 & 490660 & 13,43 & 483834 & 9,79 \\
\hline Central & 102733 & 44,30 & 126429 & 39,27 & 299216 & 28,86 & 769802 & 21,07 & 877077 & 17,74 \\
\hline Mogiana & 20341 & 8,79 & 51265 & 15,92 & 163831 & 15,80 & 811974 & 22,23 & 845442 & 17,10 \\
\hline Paulista & 2764 & 1,26 & 21889 & 6,81 & 133697 & 12,90 & 537237 & 14,71 & 661920 & 17,39 \\
\hline Araraquarense & - & - & - & - & 43697 & 4,18 & 579653 & 15,87 & 890095 & 18,01 \\
\hline Alta-sorocabana & - & - & - & - & 58004 & 5,60 & 326994 & 8,95 & 576812 & 11,67 \\
\hline Noroeste & - & - & - & - & - & 一 & 136454 & 3,74 & 608027 & 12,30 \\
\hline
\end{tabular}


E evidente que tanto a queda do volume relativo das populações das regiões norte e central como o crescimento das regiōes paulista, araraquarense, alta-sorocabana e noroeste não se deveram apenas às migrações internacionais. Houve, evidentemente, importantes movimentos populacionais internos no Brasil e entre as regiões paulistas no período que vai de 1846 a 1886, quando o volume das migrações internacionais para São Paulo ainda era desprezível. A constatação desse fenômeno coloca uma série de questões que requerem análises mais aprofundadas: qual a proporção de escravos livres na população? De onde provinha? Que tipos de funções econômicas desempenhava? Etc.

Odilon Nogueira de Matos sugere algumas respostas parciais a essas perguntas. Assim; analisando a década de 80-90, afirma à página 71: "um importante elemento lembrado por Taunay no texto atrás transcrito, veio contribuir, de maneira acen ra delinear uma nova paisagem no interior paulista: a contribuição de mineiros e fluminenses os quais, em grañdes contingentes, vieram abrir fazendas no oeste paulista, que se lhes afigurava um novo Eldorado, terrivelmente contrastante com as regiões donde provinham. Rara a cidade do ceste paulista que não tenh a troncos mineiros ou fluminenses entre os seus fundadores". O que não fica claro no texto - e tal fato não constitui defeito, porque os objetivos do livro são outros - é o volume desse contingente e como tal população se colocava na economia: eram proprietários ou trabalhadores livres? Se eram proprietários, empregavam mão-de-obra escrava ou livre na abertura dessas frentes que, como a tabela sugere, ocorreu antes da. Abolição? Enfim, o que o autor de Café e ferrovias sugere é que não se tem prestado a devida atenção às migrações internas e às suas funções no processo de desenvolvimento econômico ocorrido em São Paulo, durante o século XIX. Outra questão que não está suficientemente clara no texto - e, isso sim, constitui um dos raros defeitos substantivos do livro - é se a evolução ferroviária se deu através do emprego de trabalhadores livres. O autor esclarece que a San Paulo Railway foi construída por obrigação contratual imposta pelo Governo, utilizando o trabatho livre. Porém nada diz a esse respeito sobre todas as outras ferrovias. Ora, ainda que afirme à página 107 que "a grande expansão paulista para oeste (cafeeira e ferroviária), tendo ocorrido nos fins do século passado e nas duas primeiras décadas do século atual, livre, portanto, da conjuntura escravista, tem que ser associada ao movimento migratório que marcou a paisagem humana, social e cultural de nosso Estado...", boa parte da rede ferroviária $(2.425 \mathrm{~km}$ haviam sido construídos até 1890) foi construída antes da Abolição. É, portanto, necessário saber-se que ti-. po de mão-de-obra foi empregada lo de trabalho predominava, pois to de trabalho predominava, pois tal informação viria colaborar para o esclarecimento de questões relativas à passagem do sistema escravista para o do trabaIho livre.

Porém, essas importantes questões sugeridas pelo autor ultrapassam de muito os objetivos do livro onde, no primeiro capítulo, ele expõe o quadro geral do sistema de comunicações na província ao iniciar-se o século XIX; apresenta, em seguida, traços gerais da história do café, para, nos dois capítulos seguintes, discutir - os primórdios da era ferroviária e seu desenvolvimento. Conclui, enfim, o trabalho analisando as influências das ferrovias na paisagem paulista.

Por essas e outras razões que aqui não foram apontadas, Café e ferrovias constitui fonte indispensável a qualquer estudioso da história do Brasil do século XIX.

Manoel Tosta Berlinck

\section{Compras: principios e aplicações}

Por Paul Farrel \& Stuart F. Heinritz. São Paulo, Editora Atlas, 1972. 536 p. Indice analítico de 14 p. Traduzido por Augusto Reis, da $5 .^{a}$ edição norte-americana de Purchasing, principles and applications. Prentice-Hall, Inc.

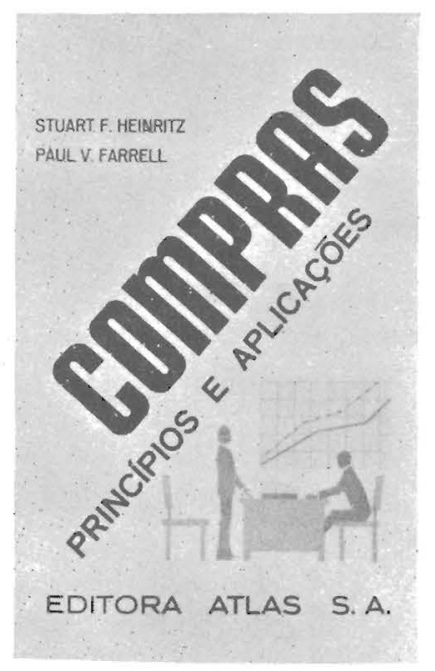

Rever este livro em português é voltar ao meu primeiro curso de compras. Sim, naquela época não se falava administração de materiais, mas simplesmente compras e o curso que fiz na Michigan State University, sob a competente direção do Prof. Hoagland, tinha como livro-texto o Heinritz. É daquele tempo $\circ$ meu permanente interesse pela ciência de compras e cada vez mais me aprofundei na aplicação da matemática que transformou compras numa área da pesquisa operacional.

A primeira edição do Heinritz saiu em 1947. De lá para cá, capítulos foram acrescidos ao livro, que se manteve num excelente nível de capacitação profissional dos seus leitores para exercer o árduo trabalho de comprador. O indice em português mostra como é completo:

\section{A função compra.}

\section{As compras e a administra- ção.}

3. A organização para as compras. 
4. O pessoal para as compras.

5. A compra da qualidade certa.

\section{Padronização.}

7. Controle de qualidade, inspeção.

8. Comprando a qua n tidade certa.

9. O controle dos almoxarifados.

10. Comprando ao preço certo.

11. A seleção da fonte adequada de fornecimento.

12. A pesquisa nas compras.

13. O planejamento e as previsōes.

14. Orçamento de materiais para adquirir.

15. Análise de valores.

16. As negociações.

17. Fabricar ou comprar.

18. A compra de equipamento de produção.

19. Sistema de compras.

20. Diretrizes de compras.

21. A ética das compras.

22. Aspectos legais das compras.

23. O cancelamento de contratos.

126 compras.

24. Avaliando o desempenho das

Estudos de casos.

Bibliografia.

Como é possivel verificar pelo índice, nada falta nesse livro, e tal impressão é reforçada pela leitura. É difícil distinguir capítulos que se sobressaem e capítulos mais fracos. O livro mantém uma uniformidade de qualidade extraordinária. Evidentemente o autor se colocou um freio quanto ao desenvolvimento matemático e mesmo de extensão e profundidade do livro - nem no caso do lote econômico há propriamente um tratamento à base de cálculo ou de considerações de pesquisa operacional (cap. 8). O livro é descritivo, não dedutivo.

Inicialmente, elimine-se da consideração do leitor uma loucura de preconceito do autor. No capitulo A ética das compras, na página 391, está o seguinte: "São práticas condenáveis nas vendas: conluios na apresentação de propostas concorrentes... o emprego de palavras e termos de negócios desconhecidos e do sistema métrico de medidas..." (sic). Com absoluta certeza, tal frase veio da época da primeira edição (1947) e da segunda (1951), pois hoje o sistema métrico é legal nos Estados Unidos, especialmente na indústria química, que está ven. dendo seus produtos rotulados metricamente desde 1966. Essa frase deveria ter sido eliminada na tradução, pois o livro não merece tal disparate.

A enumeração das funçōes de compra e a descrição de cargos da seção de compras são bem feitas, com a ressalva de que hoje é difícil encontrar um "diretor de compras"; mais comum é um "diretor de administração de materiais" ou de "planejamento da produção e compras".

No capítulo As compras e administração torna-se necessário ressalvar os problemas diuturnos que aparecem, que não são enumerados. $O$ autor é otimista no seu ponto de vista; o leitor, após 25 anos de experiência, negativo no seu - a cooperação entre compras e engenharia é necessária, mas muito dificil, pois há conflitos de interesse que o autor não pode, ou não quer, constatar ou $\mathrm{clar}$ a $\mathrm{r}$ aprofundadamente. Realmente, quando escreve que o "engenheiro de compras é geralmente um assessor de 'estafe' (usando uma nacionalização já tratada por mim na análise do livro de Sistemas e métodos de McDowell de Miranda) assessorando principalmente 0 encarregado de compras", o autor e o tradutor esquecem que no Brasil e também nos Estados Unidos o engenheiro de compras é o primeiro membro do staff a ser dispensado de apertar o parafuso da economia; ou melhor, como aconteceu numa empresa nacional muito lucrativa, por sinal - onde o engenheiro de compras foi considerado dispensável, pois os engenheiros dos departamentos e das divisóes sabiam especificar. Como isso nem sempre é um fato - e nessa empresa a especificação lembra um pouco a descrição de um lance de futebol, de gol anulado, visto por dois cronistas de times contrários - a colaboração com os engeivheiros é relativa e meio quimérica.

O autor preconiza o treinamento dos compradores por meio de rodizio nas seçōes de compras e nos fornecedores e por meio de cursos específicos de ano para ano, para mantê-los bem a par do progresso da ciência.

A descrição de carreira nas compras é problemática para 0 Brasil; a observação mostra que, dentro de "compras", o indivíduo no Brasil sobe com muita velocidade, devido à falta de matériasprimas e de pessoal adequado de compras; a primeira dá o grau de dificuldade da função, e a segunda dá o valor por escassez. Mas, em seguida, "escapar" da área de compras é definitivamente mais difícil no Brasil que nos Estados Unidos. O capítulo A com. pra de qualidade certa é exclusivamente endereçado a quem especifica e compra, mas peca por não definir as compras dentro dos limites de controle de qualidade aceitável. Falta também alguma referência aos excessos necessários na encomenda para receber o número desejado de peças de qualidade aceitável.

O capítulo 6, Padronização não deveria ter sido traduzido, mas elaborado no Brasil, pois nós temos a nossa ABNT, apesar de todas as falhas, como organismo funcionando e cumprindo seu dever. O capítulo fala em tantas palavras, que padronizar é bom, mas nos EUA padronizar é ainda uma coisa pouco difundida fora dos limites de ramos industriais.

Insuficiente $\circ$ capítulo sobre controle de qualidade, do ponto de vista do especialista, engenhei- 
ro ou professor de administração, mas suficiente para o comprador, ao qual se destina, afinal.

O capítulo Comprando a quantidade certa faz menção do lote econômico e depois mostra que tem outros métodos usados um bom capítulo com um sistema indubitavelmente válido como método de apresentação. O sistema $A B C$ não aparece no lote econômico, nem no capítulo seguinte, o nono, O controle dos almoxarifados. Por exemplo, nesse capítulo, na página 179, está a determinação do estoque reserva, por meio de curva de freqüência e suas probabilidades, o que mostra que o autors sabe colocar o que for necessário, do ponto de vista matemátiço. O interessante é que o autor usa a forma da curva de distribuição de Poisson para a determinação das exigências do estoque de segurança ( $p .180$, fig. 9-7). Lamento somente a pouca intensidade dada ao tratamento do giro do estoque (p. 190).

No capítulo Comprando ao preço certo verifica-se com prazer o uso da curva de aprendizado para a fixação do preço (p.'296).

A pesquisa da compra é um conceito inleressante do autor, infelizmente não suficiente desenvolvido. Realmente, desde a análise do valor, que merece um capítulo à parte, até a pesquisa de novas-matérias-primas e produtos, o autor dá uma excelente introdução, mas falta uma análise mais clara da diferença da pesquisa e da análise de valor.

O capítulo O planejamento e as previsões está antiquado, pois lá nada dá conhecimento dos modernos métodos estatísticos, como por exemplo, o sistema da média móvel exponencial de Brown, ou os sistemas ideados por McGee. No capítulo sobre orçamento falta um exemplo numérico para que possa ser comparada a eficácia do departamento. Otimo o capítulo Análise de valores. Fabricar ou comprar é adequadamente tratado. Os capítulos sobre sistemas e diretrizes de compras são melhor tratados pelo estudo de casos, que são juntados em grande número ao livro e que ajudam muito na concepção de um curso de compras.
Como podemos hoje usar o livro de Heinritz? Simplesmente em companhia de outro livro, também editado pela Ed. Atlas. Stockton. Sistemas básicos de controle de estoques. Os dois juntos permitem uma cobertura boa para o professor que se pode dedicar à análise de casos, que são $18 \%$ do livro em número de páginas. Tais casos, como costuma acontecer no Brasil, são fornecidos sem a parte do mestre, que de fato é desnecessário para quem realmente for mestre, mas existem outros ensinando que não podem deixar de usá-lo (a parte do mestre) por falta de tempo de preparo de aula. Aqui, então, vai um apelo para também traduzir e vender seletivamente a parte do mestre dos livros traduzidos.

Qual seria o. custo por conhecimento útil de todos os livros de compra atualmente no mercado? Evidentemente não é possível fazer uma análise de valor de custo por página impressa e, depoịs, de custo por conhecimento transmitido. No entanto, por ser um livro completo, muito bem apresentado, mesmo se algo antiquado e com inúmeros ótimos conceitos, considero o livro de Heinritz atualmente uma compra excelente no campo de livros de compras e um volume recomendável para todas as bibliotecas de empresas.

Kurt Ernst Weil

\section{- municipio como sistema político}

Por Ana Maria Brasileiro. Rio de Janeiro, Fundação Getulio Vargas, 1973. $124 \mathrm{p}$.

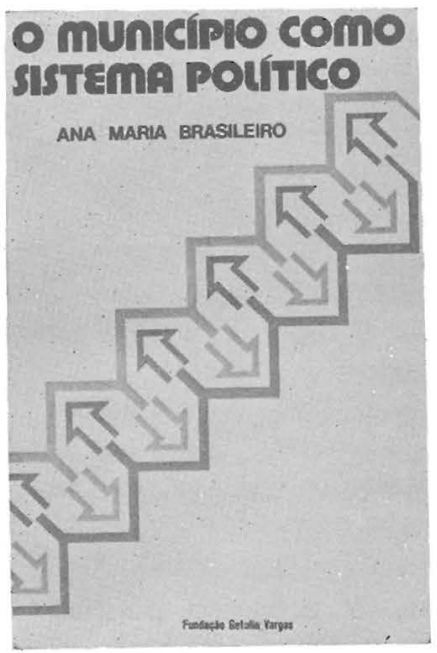

O pequeno livro de Ana Maria Brasileiro tem como objetivo contribuir para o conhecimento da realidade brasileira através do estudo do governo local em um País que se encontra em processo de desenvolvimento.

Na parte 1 - O município como sistema político - "encontra-se visão global do município brasileiro, partindo-se de um enfoque jurídico-histórico para um estudo sob a ótica sistêmica". A parte 2 - Os sistemas locais no Estado do Rio de Janeiro - analisa e compara municípios do Estado do Rio de Janeiro.

No primeiro capítulo, Evolução do governo local no Brasil, encontramos um excelente resumo de como o poder local se comportou desde o século XVI até os dias atuais. Para traçar a perspectiva histórica de um período que abrange quase 500 anos, a autora utilizou-se das Constituições outorgadas e/ou promulgadas nesse longo intervalo e de trabaIhos de conhecidos cientistas sociais brasileiros. Podemos notar a posição singular do município em nosso País "que tem sido, tradicionalmente, a unidade de governo local no Brasil, em contraste 
flagrante com o que ocorre em outros países onde existe a proliferação das unidades de governo local (o condado, a cidade, 0 distrito escolar e os distritos especiais). Como conseqüência, o município brasileiro caracteriza-se, também, por englobar, em seu território, tanto áreas urbanas quanto rurais" (p. 3 ).

Verificaremos que apenas a Constituição de 1946, conhecida como a. "constituição municipalista", via a idéia de controle em termos incompativeis com o conceito de autonomia política. Além disso, fazia inovaçö̌es importantes, como por exemplo, permitir que o municipio partilhasse da arrecadação dos tributos estaduais e federais.

Com o Golpe de Estado de 1964, o processo político sofre uma maior centralização e, conseqüentemente, a autonomia municipal sofre novos abalos, tais como.a reforma do sistema tributário, tornando-o mais dependente dos recursos transferidos e vinculados a minuciosos planos de aplicação.

Nos capítulos 2 a 5, a autora realiza um estudo sob o ponto de vista da ótica sistêmica. A metodologia sistêmica utilizada faz com que o leitor enxergue claramente - que é o município brasileiro, qual a sua função no interior do sistema político, quais as relaçōes de dependência que mantém com as outras partes, $\circ$ que é necessário para o funcionamento do sistema, como as necessidades transformam-se em produtos através de um processo de conversão,

Como gostam de afirmar os teóricos das organizaçóes, se tudo for fixado em termos de objetivos, "o real torna-se mais palpável" e consegue-se obter "uma visão global da realidade". Cristaliza-se, então, a grande vantagem da abordagem histórica, qual seja a de permitir uma síntese "eficiente" de uma realidade por vezes complexa. Quando isso é concretizado, a história fica relegada a um plano secundário apesar da negaçāo dos sistêmicos.
A nosso ver, o grande mérito do livro foi o de conciliar as duas abordagens: a historicista e a objetivista. A primeira é realizada em apenas 10 páginas, mas com uma precisão e síntese invejáveis, ao passo que a objetivista o é durante aproximadamente uma centena de páginas. Dessa forma, a abordagem microssociológica pre domina através do enfoque sistêmico sobre a historicista.

Afirma a autora que "o município brasileiro - uma organização formal com limites territoriais claramente demarcados e população estabelecida - pode ser visto como um importante subsistema em si próprio, dependendo dos propósitos da análise" (p. 13). Procura, também, definir e delimitar o que vem a ser um sistema simples, um sistema político, as funçōes do sistema social, insumos, produtos, feodback, etc. "Os insumos do sistema municipal podem ser classificados em duas grandes categorias: demandas e apoio, sendo que, ao nivel local tomam a forma de reivindicaçōes de serviços, regulamentaçöes, licenças especiais, empregos públicos e outros privilégios particulares" (p. 27). Quanto à participação da massa de indivíduos no município típico brasileiro, "... encontra-se alienada do processo de formulaçōes de demanda ao sistema político, cuja condicionante é a própria pobreza dos municípios" (p, 29). Formase, então, um círculo vicioso: o municipio é pobre e não pode satisfazer às reivindicaçōes do "povo", e este mesmo "povo" já nada espera do município; sabe que sua pobreza fará com que a "salvação" venha das esferas superiores através das receitas transferidas e/ou da astúcia do prefeito e cidadãos locais que gozem de prestígio junto ao governo central. O livro de Mário Palmério, Vila dos Confins, fornece-nos um exemplo típico dessas práticas.

A dependência dos municípios com relação às esferas superiores é diretamenle proporcional ao montante das receitas transferidas. Assim é que a autora, na página 24, mostra-nos que a dis- tribuição das receitas tributárias entre os municipios, para o periodo de 1960-67, foi a seguinte: receitas do Governo federal $48 \%$; receitas do governo estadual $-43 \%$ e receitas municipais - $9 \%$. Portanto, o municipio fica a mercê dos governos federal estadual. Toda essa conjuntura alia-se à promulgação do Ato Institucional $n .^{\circ} 2$ de 27.11.65, que extinguiu os 14 partidos políticos existentes na época. Deve-se ressaltar, também, que algumas conseqüências desfavoráveis foram criadas para os municípios pequenos e sem recursos, através da Emenda Constitucional n. 18 e Constituição de 1967, em termos de arrecadação de tributos.

Quanto ao processo de conversão de insumos em produtos, afirma que "... é o processo politico por excelência. Envolve o problema da escolha entre as diversas alternativas que se apresentam..." (p. 45).

Os produtos do sistema municipal são divididos em dụas categorias gerais: os de serviços e os de regulamentação. Os primeiros compreendem bens e serviços prestados a seus membros, ao passo que os de regulamentação são constituídos por normas e leis.

No ultimo capítulo da parte 1 , a autora afirma que "o mecanismo pelo qual os membros do sistema reagem a seus produtos, e - sistema ao comportamento de seus membros, é conhecido como o processo de 'feedback' “ (p. 63).

Concluindo, podemos afirmar que, se $\circ$ município não sofre pressōes por parte de seus habitantes, o nível do produto que apresentará será baixo.

$\mathrm{Na}$ parte 2 - Os sistemas locais no Estado do Rio de Janeiro - a autora considera como insumos os recursos financeiros e como produtos os gastos governamentais. Através de um trabaTho de campo procura analisar e comparar os 63 municipios (divididos em 273 distritos) do Estado do Rio de Janeiro. Com base em seu estudo sobre a organiza. ção político-administrativa e das formas como são obtidos e gas- 
tos os recursos nos municípios estudados, busca comprovar, empiricamente, algumas conclusões firmadas na parte 1 e estimular outras pesquisas que visem esclarecer e propor soluçōes com o objetivo de sanar o hiato existente entre o "papel" que lhe é conferido pela Constituição brasileira e sua "posiçāo" e peso reais.

Com o objetivo de demonstrar que as reformas introduzidas no sistema tributário brasileiro a partir de 1966 fizeram com que - município ficasse na dependência cada vez maior dos recursos transferidos das esferas superia res, constrói um quadro ( $p .73$ ) onde registra a receita municipal em dois anos, a saber, 1965 e 1967. No primeiro, o percentual de recursos transferidos foi da ordem de $13,1 \%$, ao passo que em 1967 foi de 50,2\%. Assim sendo, a autora chegou à conclusão de que, no Estado do Rio de Janeiro - e cremos que, por extensão, em todos os estadosmembros da União - a autona mia municipal sofreu um grande impacto. Nas páginas seguintes, através de um instrumental estatístico relativamente simples, (correlaçöes simples, freqüência, medianas, variâncias, médias aritméticas, etc.), a maioria das conclusōes teóricas puderam ser corroboradas no nível empírico.

Ana Maria Brasileiro chega à conclusão de que "... os gover. nos locais, no Brasil, não foram, aié agora, realmente, integrados no processo de desenvolvimento do País. As ações modernizantes originam-se nas esferas superiores de governo, mas não contam com - apoio efetivo dos governos locais" (p. 107). Afirma, ademais, que ultimamente têm-se registrado diversas tentativas no sentido de fazer com que os governos locais participem do processo, mas isso ainda não se deu, entre outros fatores, pela falta de um programa efetivo de assistência técnica aos municípios e pelo desenvolvimento de planos estratégias em termos nacionais, que, em geral, prendem-se a um tecnicismo exagerado e infenso às peculiaridades locais.
Concluindo, podemos afirmar que a autora conseguiu tratar de um tema amplo e complexo, reduzindo o texto a pouco mais de 100 páginas. Recomendamos sua leitura aos interessados nos problemas municipalistas e em ciências sociais em geral.

\section{Afrânio Mendes Catani}

\section{Getúlio Vargas - Biografia política}

Por John W. F. Dulles. Rio de Janeiro, Renes, 1967. $408 \mathrm{p}$.

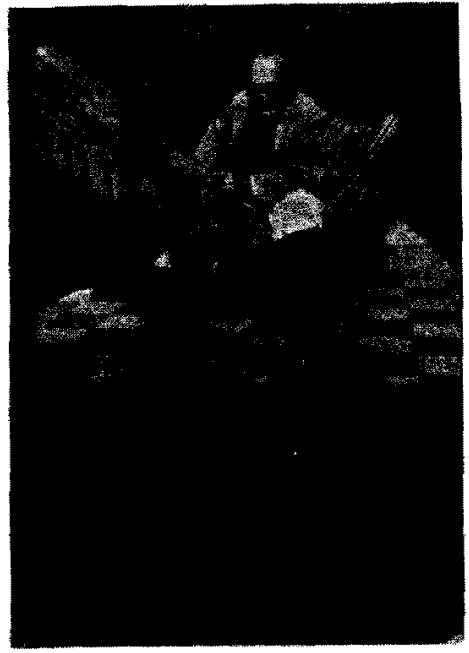

A biografia política de Getúlio Vargas por John W. F. Dulles apresenta-se como uma narrativa dos principais acontecimentos políticos na compreensão do processo histórico que levou à expansão e consolidação do poder do Estado. Não apenas por tratar-se da figura de um lider cuja presença não pode ser dissociada do referido processo como também pela tentativa por parte do autor em retratar a atuação de Vargas como um líder moderador. Assim, a ordenação dos fatos considerados relevantes desenvolve-se principalmente com vistas a esta última possibilidade.

Através de uma perspectiva histórica de corte mais factual do que interpretativo, o autor organizou o livro por períodos que abrangem desde as características gerais da conjuntura pré-revolução de 1930, passando pela implantaçäo do Estado Novo (1937-45), até a volta de Vargas ao poder como presidente constitucional (1951-54).

Já na parte inicial, onde são focalizados aspectos relacionados com a caracterizaçăo da conjuntura política da Primeira República, podemos discernir o início da trajetória de Vargas no cenário da política nacional.

"Um homem quieto, com boa memória e ampla leitura de obras 
filosóficas", Getúlio ingressa na vida polítjca de seu estado em 1909 como deputado eleito para a assembléia estadual gaúcha.

A importância dos PRs estaduais no esquema da organização partidária vigente na Primeira República aliada a uma tradição familiar — "o pai de Getúlio... nomeado general honorário do exército... se tornara seguidor de Júlio de Castilhos e procurou instilar nos filhos a devoção aos princípios do partido Republicano" - fez de Getúlio um membro ativo do PR rio-grandense.

Sob a tutela do caudilho Borges de Medeiros tornou-se, já em 1921, líder da maioria na assembléia estadual. Entretanto, a presença de Vargas no plano da política federal não nos parece significativa até fins da década de 20, quando então é nomeado para ccupar a liderança da pasta da fazenda - "um cargo que apresentava desvantagens para o político sempre disposto a "assumir posição compreensiva e amável".

Por outro lado, a análise de al. guns elementos de crise que compõem o processo histórico-político anterior à Revolução de 1930 leva o autor a verificar a importância de outro personagem. Referimo-nos à figura de Luís Carlos Prestes - "engenheiro militar... com brilhante passado acadêmico a responsável pela construção em 1924 de uma linha ferroviária no Rio Grande do Sul" (p. 39).

E interessante notar que, com o ascenso dos movimentos reformistas da pequena burguesia nos anos 20, a figura de Prestes, em contiaposição a Vargas, revela-se bastante significativa na medida em que mobiliza e/ou é portadora de reivindicações de uma parcela da população (ou de um grupo social).

Esta possibilidade, a nosso ver, torna.se ainda mais sedutora a partir do momento em que o "Cavaleiro da Esperança" recusa - oferecimento de Oswaldo Aranha - líder tenentista - para que assumisse a chefia militar do movimento revolucionário em outubro de 1930.

Para ele, "uma revolução liderada pela Aliança não seria mais do que outro capítulo na luta tradicional pelo poder" (p. 66).

Logo após a Revolução de 1930, justamente quando o relato dos acontecimentos evidencia o poder de barganha dos tenentes, a orientação de Prestes no plano ideológico revela-se incompatível com as soluções preconizadas pelo Clube 3 de cutubro.

Com referência à conjuntura política dos anos 1934-35, propícia à adoção de certas medidas que vieram em parte favorecer a implantação do Estado Novo, Dulles enfatiza a atuação dos diversos partidos (AIB, ANL), ao mesmo tempo em que procura cristalizar a posição de Vargas como "o protótipo do moderador judicioso".

Neste conteñto, Frestes, então no auge de seu prestígio, etorna ao País em abril de 1735 após uma visita realizada à UPSS e torna-se membro do Comitê Político do Pr.

Em relação ao setor mais forte da esquerda, esta adesão certamente iria assumir uma conotação mais profunda no plano da influência ideológica.

Dulles considera que "durante - curto período de 15 anos Vargas prejudicou o movimenio comunista não tanto com medidas policiais quanto pela legislação social que promulgou, e pela criação do PTB".

Cabe mencionar que, a partir dos ancs 30, a análise de uma série de decretos e leıs sociais revela uma vinculação da tipo paternalista entre o poder central e a classe operária, cristálizando assim uma política de incorpoiação.

Considerações dessa ordem, entretanto, não constituem objeto de preocupação iniaior por parte do auior.

No mais, Dulles revela-se um exímio pesquisador, apresentando - livro bibliografía bastante interessente. Entretanto, apesar do seu eficiente apego à pesquisa, Dulles não consegue remover a Evidënciā de que Vargas ainda espera seu biógrafo.

Antonio Carlos Sachs
The Vargas regime: the critical years 1934 - 1938

Por Robert M. Levine. New York, Columbia University Press, 1970.

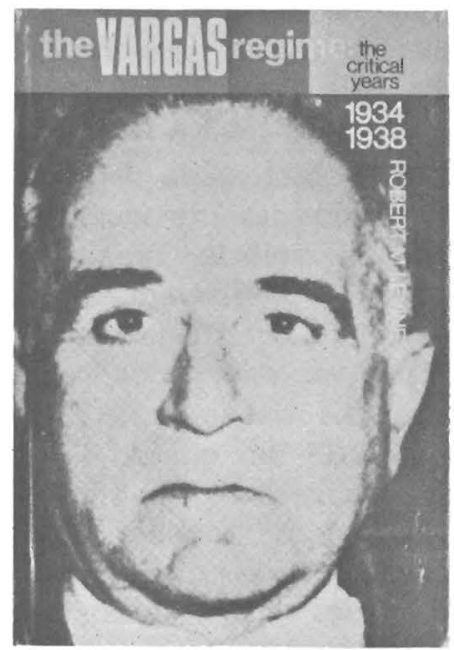

Ao se instalar a Assembléia Constituinte em 1934, as manifestações dissidentes das oligarquias estaduais foram transpostas para - plano do debate parlamentar. Tendo a Constituinte posteriormente se transformado em Assembléia Legislativa, Vargas estava com seu poder restringido. A continuidade desse sistema não mais justificaria um governo executivo com as forças que tinha ou com as que Vargas queria. Surgem nesse momento duas forças políticas opostas que servirão de bode expiatório para uma reconcentração de forças no poder executivo: a Aliança Nacional Libertadora e a Ação Integralista Brasileira. Durante quatro anos (até 10 de novembro de 1937), Vargas aproveitar-se-ia desse choque de forças para mostrar ao Congresso sua própria ineficácia e por fim fechá-lo em nome da segurança nacional. Essa é a visão que Levine tem do período e essa é a abordagem do livro.

Ao privilegiar um aspecto da realidade, colocando o próprio Vargas como um "Deus ex-machina", observando o desenrolar dos acontecimentos e utilizando-se de um vasto material documental, o autor oferece um histórico detaIhado dos fatos e homens envolvidos em tais movimentos. A esse respeito o autor traça paralelos 
entre ambos os movimentos, dando a entender que suas distinções básicas consistiam apenas no fato de o primeiro ser antifascista e o segundo anticomunista, pois que a origem social dos componentes de ambos era similar (em sua maioria, eram compostos de segmentos médios urbanos: burocratas, profissionais liberais, militares, etc.) e suas plataformas políticas não apresentavam diferenças significativas (independência econômica, educação do "povo", nacionalismo, etc.).

A criação da ANL, em março de 1935, teria sido "encorajada" pelo $P C B$ e contava em seus quadros com elementos do movimento tenentista, principalmente da ala Prestes-Miguel Costa. E não era por coincidência que suas reuniōes se faziam em cômodos anteriormente ocupados pelo Clube 3 de Outubro. O nome de Prestes, nomeado seu presidente honorário em sua primeira manifestação pública, vincula a ANL ao PCB, muito embora sua ação se desenvolva com relativa independência aié meados de 1935 . Por essa época a leitura que o então estudante Carlos Lacerda fez do Manifesto de Prestes para uma pequena multidão no Estádio Brasil assinala o ponto final da ascensão política da ANL. O movimento radicaliza-se dai para frente, sendo totalmente controlado pelo $\mathrm{PCB}$, ou seja, for Prestes e enviados do Comin ern. Essa situaçãa culmina com a ação de novembro de 1935.

Relatando as atividades de novembro, o autor descreve a rebeliāo no Rio Grande do Norte e a quase instalação da República Soviética do Rio Grande do Norte. A ação. ocorrida nesse estado, antecipando se a uma possível ação de amplitude nacional, provocada por um pequeno grupo de militares, nada mais foi do que uma escaramuça de quartel e que só logrou o pequeno êxito que teve graças à inconsistente defesa com que contava o desprotegido estado.

Da Ação Integralista $\circ$ autor destaca sua estrutura burocrática organizada sob a forma de células espalhadas por quase todo o território nacional, que se subordinavam às administrações distritais, que, por sua vez, se reportavam à Câmara dos Quatrocentos e esta à Câmara dos Quarenta, que era escolhida pelo Supremo Conselho Integralista do qual Plínio Salgado era o mandatário supremo. A AlB contava com membros que pertenciam à alta hierarquia da burocracia civil e militar, o que pode explicar a complacência que gozava junto ao Estado. Ela passa a ter força manifesta a partir de fins de 1934, atinge seu clímax na marcha de 1. de novembro de 1937 no Rio de Janeiro e é desarticulada a partir da tentativa de assalto ao Palácio Guanabara, então residência do chefe do Governo, em princípios de 1938

Pairando acima dessas corren. tes extremistas estava o Estado, com seu poder fortificado desde 1930.

A partir da repressão do movimento de novembro de 1935 inicia-se dentro do Estado uma reação em cadeia no sentido de reforçar seus aparelhos repressivos: os 90 dias iniciais de estado de sítio autorizado pelo Congresso são renovados por mais cinco vezes; Góes Monteiro advogava uma revisão constitucional para manter a ordem nas Forças Armadas; é formada a Comissão Nacional de Repressão ao Comunismo e a Polícia é reforçada com poderes discricionários. Um golpe de estado estava iminente. Como causas mais importantes desse golpe - autor aponta as seguintes:

a) o apoio dos militares para uma centralização do poder, pois sentiam a hierarquia das forças Armadas ameaçada pela infiltração comunista;

b) a incômoda situação política no Rio Grande do Sul causada por Flores da Cunha e sua milicia estadual fora da esfera de controle do exército nacional;

c) a mudança de direção na campanha de José Américo que se afastava cada vez mais dos padrões tradicionais, buscando apoio político nas classes populares e criticando a administração de Vargas: d) o célebre Plano Cohen e seus conhecidos efeitos de uma guinada para a direita na política, através da criação das Comissóes de Estado de Guerra em cada estado da União;

e) a atuação dessas comissões através de seus podéres discricio nários serviram para desalojar o maior oponente de Vargas: Flores da Cunha no Rio Grande do Sul, bem como minimizar as atuações de Lima Cavalcanti em Pernambuco e Juracy Magalhães na Bahia, que eram não apenas favoráveis à realização das eleições, como se haviam posto contra o esquema montado por Vargas.

E o manifesto enviado por Armando Salles ao Congresso no dia $8 \mathrm{fez}$ com que se antecipasse - golpe para o dia 10 de novembro.

De um modo geral, na leitura do livro, tem-se a impressão de uma interpretação psicologizante dos acontecimentos, onde "indivíduos" se confrontam com um sistema ou onde os "Estados" reivindicam privilégios. Individuos e estados que nos são apresentados desvinculados de grupos sociais, interesses especificos, etc. Quanto ao próprio Vargas, 0 autor 0 apresenta no início de sua administraçăo como um "imprevisivel enigma político" sem ideologia determinada e que herda desses movimentos o nacionalismo como ideologia de uso populista.

Isso porém não compromete o livro, que é produto de uma avul. tada quantidade de material coletado em fontes originais e nem sempre de fácil acesso. $O$ autor que já antes organizara um livro sobre fontes para pesquisa histórica no Brasil (Brazil: field research guide) trabalha cuidadosamente sobre os dados coletados, permeando as análises mais globais dos fatos históricos com dados biográficos dos personagens envolvidos. Negando-se a seguir pela linha mais tradicional de análise (Getúlio às voltas com a Assembléia Legislativa) Levine fornece-nos uma perspectiva ampla dos movimentos extremistas do periodo e seus conflitos entre si e com o Estado.

Paulo Lollato 


\section{Administração da produção}

Por Elwood S. Buffa. Rio de Janeiro, Livros Técnicos e Científicos Editora, 1972. 2 v., 780 e XVI p., índice alfabético, ilustrado, impresso ein duas cores, traduzido pelo Alm. Otacílio Cunha da 3. ${ }^{\circ}$ ed. em inglês de: Buffa. Modern production management. John Wiley and Sons, 1969

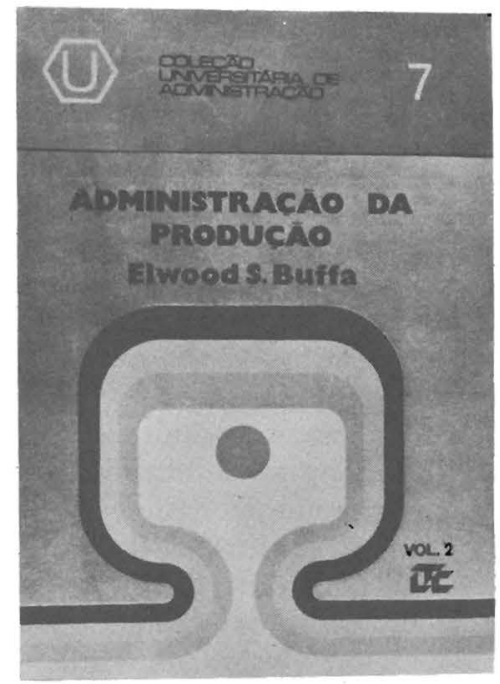

Completando uma série de li vros que ensinarn administração da produção, foi finalmente traduzido o livro principal de Buffa, aquele que todos os profissionais, engenheiros e administradores com treinameito nos Estados Unidos tiveram provavelmenie coino texto principal ou leitura correlata. Atualmente existem no Brasil as seguintes traduções nessa área: Starr. Administração da produção. (Ed. Universidade São Paulo), Mayer. Administração da produção, (Editora Atlas) e agora, ainda com o mesmo título, o livro de Buffa. Além disso, existem dois manuais de administração, um em fascículos, de Maynard, que em inglês é apresentado em um só volume, e um em dois volumés, de professores da Fundação Getulio Vargas. Todos esses livros são de utilidade mas a metodologia seguida pode ser dividida em quatro escolas diferentes:
1. A escola clássica - Mayer que sistematicamente estuda as funções de produção.

2. Uma escola moderna, usando - conceito de sistema, mas dentro do esquema ainda clássico, funcional, temperado com metodologia interdisciplinar: Buffa.

3. A escola do "sistema", usando a metodologia global, simultânea, que pressupõe conhecimentos prévios da matéria e que repete certos conceitos pela multiplicidade do ataque ao problema.

4. O estudo global, em capítulos, sistemático, mas podendo ser lido e usado como texto em diversas disciplinas, de Maynaid, e, como livro nacional, o de Sá Motta, Machline, Weil e Schoeps.

Para o ensino em nível de graduação, na opinião deste iesenhista, o livro de Buffa é ótimo, mas exige muito. Ele adapta-se aos cursos de pós-graduação para pessoal não-especializado em engenharia de produção. Após o estudo de Buffa, o livro de Starr tcrna-se fácil para cursos de pósgiaduação.

O livro de Buffa tem muitos fatores a seu favor: ótima apresentação gráfica onde os pontos impor.antes são realçados pelo uso de uma segunda cor (vermetho) e facilidade de manuseio pela divisão em dois volumes, que permitem baratear o livro pela possibilidade de usá-lo como brochura e papel grosso e resistente.

A terceira edição em inglês distingue-se da segunda (que já foi resenhada nesta revista) por conter muitas novidades no planejamento, pela maior importância de redes e por ter juntado a psicolcgia do irabalho, ampliação de tarefas a motivação em um único capílulo. Como Buffa é especialista de administração de materiais, é claro que essa área sofre uma radical transformação entre as edições de 1965 e 1969, onde novos conceitos importantes, especialmente de probabilidades e estatísticos foram introduzidos, talvez pela ação de Starr na Universidade de Columbia, em Nova York. Portanto, a quinta parte do livro, Planejamenio e controle das cperações, nos capítulos 15 a 17 , está renovada.

O conteúdo de um livro de produção é condicionado peló método de exposição. A engenharia industrial foi a origem dos livros de administração da produção para escolas de administração de empresas. Muito tempo passou até que aparecesse um Buffa, discipulo de Barnes, para alargar o campo restrito ao estudo de tempos e métodos, layout, cronogra. mas e planejamento de estoques, administração de pessoal e controle de qualidade. O resultado é um estudo onde a programação linear se éncontra ao lado dos métodos clássicos e programação. O estudo da localização de empresas só aparece após a verificação de quanto custa o montante a investir, onde estão os mercados potenciais dos eventuais produtos, etc. A contabilidade de custos tomou, praticamente, o papel do cronometrista como medidor de produtividade fabril. Buffa foi um dos homens que conseguiu essa renovação e ainda não parou aí, mas adiantou-se até os tempos modernos, integrando o programa de computador para acionar máquinas, para projetar mercadologicamente a produção e para estudar modelos.

E com prazer que fazemos recomendação irrestrita deste livro. Nenhuma biblioteca de fábrica deve dispensá-lo. O currículo do engenheiro, administrador e do economista industrial necessita do livro, e o Contador (com C maiúsculo) deve ter lido os capítulos principais para completar sua formação.

Relacionamos abaixo os capitulos dos livros de Starr e Buffa de forma a estabelecer uma correlação comparativa entre ambos, visando facilitar o estudo daqueles que se propõem a trabalhar com essa área da administração: 


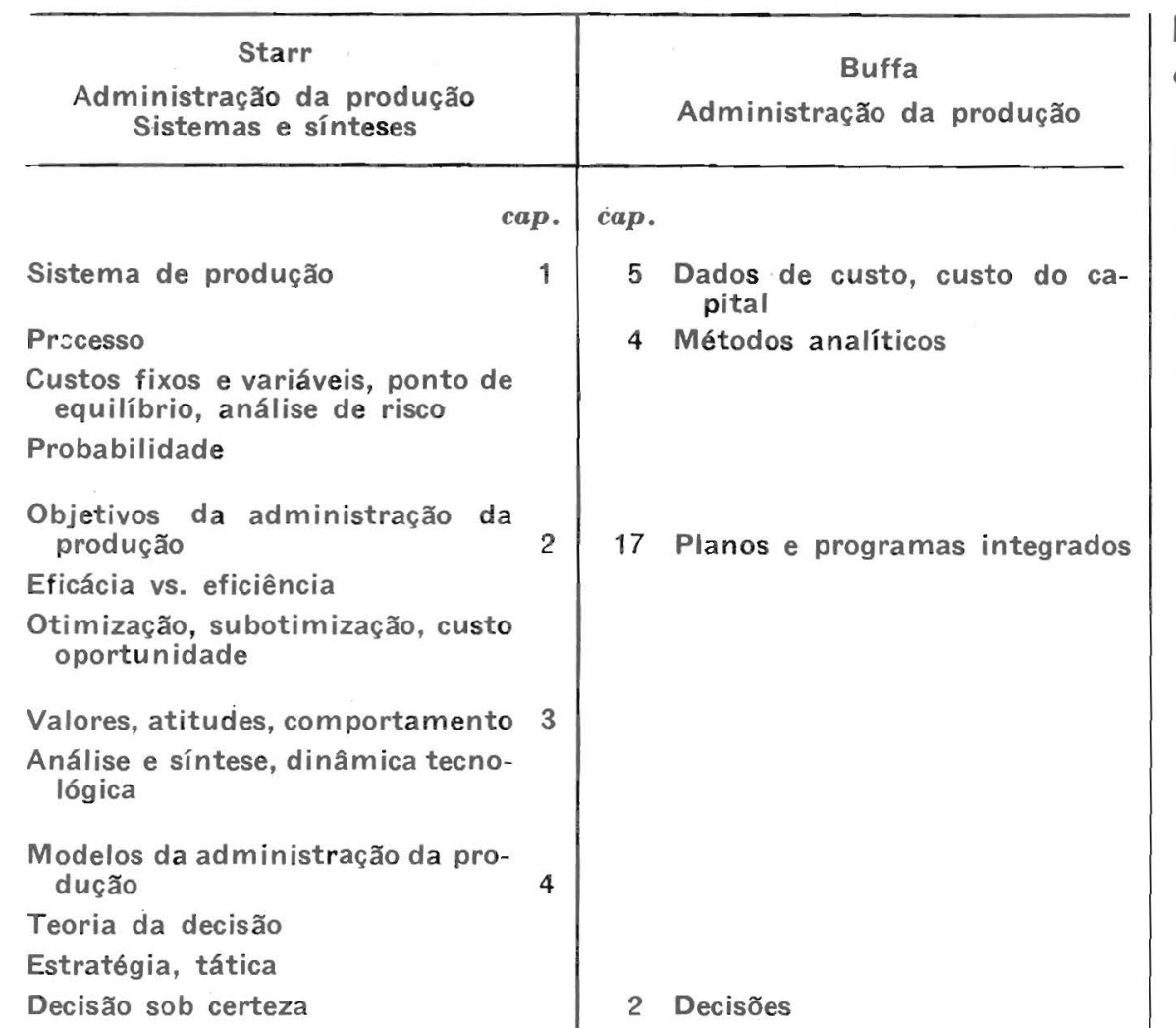

Risco, incerteza

Matriz do gráfico do ponto de equilíbrio

Modelos de planejamento a longo prazo

Análise de sensibilidade

Receptividade

Gráfico de Gantt

Análise dimensional

Horizonte planejamento

Modelos de comportamento

Fatores humanos

Modelos anatômicos

Sistemas sensoriais

Segurança

Interação homem-máquina

Modelos de estimação

Modelos competitivos

Incentivos salariais

Modelos heurísticos

Modelos de controle

Tipos de controle

Previsões

Controle com realimentação

Sistemas abertos e fechados

Cibernética

Matriz de controle

Detenção de falha

\section{Reportagens que abalaram - Brasil}

Por Francisco de Assis Barbosa, Justino Martins, Joel Silveira, Edmar Morel, Carlos Lacerda, David Nasser, Samuel Wainer, João Martins, Darwin Brandão, Murilo Melo Filho, Otto Lara Rezende. Bloch Editores, 1973.

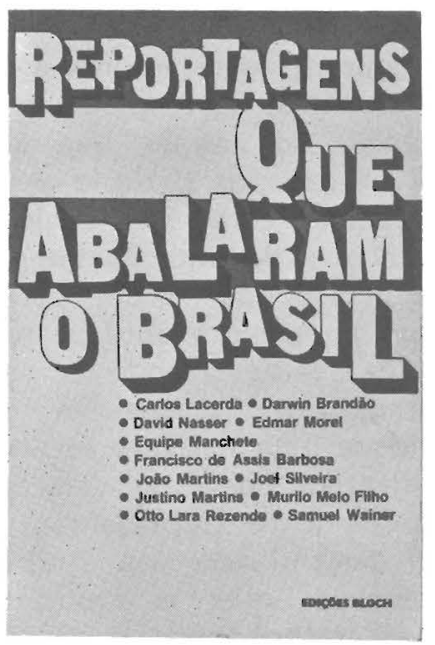

Segundo Peter Berger, "a linguagem possui a qualidade da objetividade e a capacidade de transcender o 'aqui e agora' integrando a realidade numa totalidade dotada de sentido, podendo atualizar objetos distanciados espacial e temporalmente. Nos campos semânticos, a experiência pode ser objetivada, conservada e acumulada. A acumulação, está claro, é seletiva, pois os campos semânticos determinam a quilo que será retido e o que será 'esquecido' como partes da experiência total do indivíduo na sociedade." (Berger, Peter. A construção social da realidade. p. 58 e segs).

E devido a esta capacidade de transcendência da linguagem e de acumulação dos campos semânticos que nos podemos reporta a uma realidade histórica longínqua e tentar, através de seus elementos objetivados, conhecê-la e reconstruíla em seus nexos significativos. Neste sentido, um exame de conteúdo de textos jornalísticos pode ser um material 
muito rico, se observarmos este conteúdo em suas implicações ideológicas e as relações destas com o campo do poder político.

A coletânea reúne uma série de reportagens publicadas entre 1940 e 1955. Na introdução, Magalhães Júnior diz se tratar de "reportagens que marcam momentos críticos na vida brasileira nos quinze anos que vão de 1940 a 1955" e que "a iniciativa se justifica pela seleção dos textos que figuram neste volume e o titulo escolhido corresponde à importância dos temas que abordam". Apesar de o título se justificar mais como um apelo comercial e a delimitação temporal não corresponder a um período dotado de alguma unidade histćrica, oj textos quando tornados separadamente conservam una qualidade informativa e estilística significativa. Por estas características, os lextos representam um tipo determinado de trabalho joinalístico que se modificou através das próprias transformações sofridas pelos canais encarregados na transmissão de informações. Percebe-se umı jornalista engajado em sua função, atuanre, indo em busca da noticia, dividindo com o jornal a responsabilidade da publicação, ou seja, personificando todas as eta pas de elaboração da informação. Esta personificação dilui-se atualmeilte, quando é incorporada ao perfil do órgão a que se filia o jcrnalista.

Se tentarmos estabelecer algum. iraço de união entre as reportagens, poderíamos agrupar as que foram publicadas durante a presidêricia de Getúlio Vargas ou, ainda, as que têm em mira o

próprio Getúlio em diversos momentos de sua atuação.

As declarações de José Américo de Almeida a Carlos Lacerda, publicadas no Correio da Manhã em 22 de fevereiro de 1945, são representativas de um momento político que já se efelivara na prática. A movimentação da oposiçâo liberal vinha-se articulando sob a bandeira da institucionaliração do regine e abertura do processo político. Neste sentido as declarações de José Américo corporificam o esvaziamento das a ntigas alianças políticas que apoiavam Vargas, o que se evidencia também pela quebra da censura exercida sobre os canais de informação.

Sob a direção de Azevedo Amaral e Samuel Wainer surge em 1938 o semanário Diretrizes, do qual são retiradas três das 14 reportagens que compõem o livro. A primeira delas é o depoimento do Coronel Dilermando de Assis sobre a morte de Euclides da Cunha. O coronel aparece como uma pessoa de fortes princípios morais, integra, vítima de uma tragédia que marca toda sua tra. jetória a partir de seus 17 anos, quando inicia sua relação com a mulher de Euclides da Cunha. A partir do relato, Euclides aparece como uma pessoa com características de um temperamentalismo agressivo e com a vida conjugal bastante abalada. O escritor morre quando de uma invasão à casa de Dilermando, onde, armado, atinge o irmão deste que adquire uma paralisia causada pela bala. O tiro que mata Euclides é da arma de Dilermando. Este se casa tempos depois com a viúva do escritor com quem já tinha um filho. A tragédia assume tons ainda mais negros quando, anos mais tarde, o filho mais velho de Euclides da Cunha tenta vingar - pal, atirando contra o padrasto. Dilermando mais uma vez mata, defendendo-se. A reportagem é a junção de uma série de depoimentos do Coronel 30 anos depcis da morte do autor de Os sertõas numa tentativa de transfcrmar a mística que se criou em torno da figura e circunstâncias que rodearam a morte de Euclides, tido como vítima de traição, proteıor de seu assassino, etc

A segunda delas é a excelente crônica de Joel Silveira "Grã-finos em São Paulo", publicada em 1943, onde o autor dá mostras de um agudo senso crítico na observação do comportamento da alta burguesia paulistana em todos os seus maneirismos e estereótipos. Silveira caracteriza três grupos entre os grã-finos: os de quatrocentos anos, grã-finos de pedigree, que se vangloriam de suas origens e feitos - "ser um paulista de quatrocentos anos e mais importante do que ter estátua na praça pública. O poeta Olegário Mariano tem uma estátua na praça pública e passa despercebido na Rua do Ouvidor. Um paulista de quatrocentos anos jamais será confundido na multidão da Rua Direita" (p. 81). O segundo grupo é composto pelos italianos ricos, donos de empresas bem sucedidas, que segundo - autor "têm olhos derramados sobre a gente de pedigree" ( $p$. 81 ). O terceiro é o grupo do "estribo e do penacho", formado de médicos de Barretos e comerciantes de Bauru: "As mulheres sacrificam os maridos, fazem milagres no orçamento mensal contanto que se tornem dignas do Roof ou do Jequiti. E o grupo do 'estribo' e o grupo do 'penacho'. Os homens se dependuram na vida mundana de São Paulo como se estivessem num bonde cheio. As mulheres usam terriveis penachos porque acreditam ser isto a característica principal da grã-fina" (p. 81-2).

Ainda do mesmo autor, "A 1002." noite da Av. Paulista", publicada dois anos depois, estabelece uma linha de continuidade com a primeira. E o relato do casamento da filha do Conde Francisco Matarazzo que movimentou a Paulicéia e a cuja festa Joel Silveira não compareceu devido às indiscrições cometidas no primeiro artigo. Ainda assim, - jornalista tece seu sarcasmo a partir do relato de um convidado e define o acontecimento como "O Congresso da grã-finagem nacional antes tão dispersa em seus movimentos, e que agora, atraída pela força magnética do Conde Matarazzo, se confundia num blcco interestadual, poderoso e aurifulgente" (p. 77).

Por coincidir com o periodo da Guerra, a descrição torna-se ainda mais grotesca quando se comparam as duas realidades que são opostas de forma mais direta no texto que completa o quadro "Farpa não eirira en fila" de autoria de Edmar Morel publicado n'O Jornal, recentemente extinto. Farpa é uma égua de corrida que em sua pacífica morada no Jóquei Clube desconhece as filas que se formam em frente ao 
caminhão que distribuía leite, popularmente chamado "vaca leiteira", numa época de racionamento de diversos produtos alimentícios. A publicação do artigo provoca uma série de invasōes a estabelecimentos distribuidores de gêneros.

O terceiro artigo publicado em Diretrizes é o de Justino Martins - "Como era verdade o meu Brasil" - frase que lhe ocorreu quando da observação do mapa do Brasil demarcado por bandeirinhas verdes que assinalavam os núcleos integralistas espalhados em sua extensão e parodiava o título de um romance de Richard Llewellyn - Como era verde o meu vale em moda no momento. ${ }^{1}$

Martins desenvolve numa linguagem jornalística a história do movimento integralista a partir de suas origens como tal, no inicio da década de 30 até a repressão desencadeada şobre a organização em 1938, sugerindo que a repressão sobre os núcleos organizados não significa a extinção do integralismo. O autor reportase ao anedótico da formação do movimento estabelecendo relaçōes com o modelo nazi-fascista eura peu em que se inspiravam os "camisas-verdes". Por exemplo, sua descrição da elaboração dos símbolos distintivos do integralismo: "Numa reunião com seus principais chefes, Plínio cria o distintivo e a bandeira azul e branca do Sigma assim como o fardamento. Teme o ridículo disso tudo mas năo hesita mais. Há uma série de detalhes a estudar. A moda é de calças boca-de-sino, para os homens. Plínio percebe que este tipo de calças atrapalhará um pouco nas futuras marchas e desenha uma calça meiacanela. Há, porém, alguns elegantes que protestam e, finalmente, fica resolvido que a calça seja simplesmente 'uma calça'. Por outro lado, surge o problema da camisa. Estuda-se uma cor. Verde? Azul? Vermelha? Preta... Na Itália elas são pretas. Na Alemanha são pardas. Fica resolvido que no Brasil elas sejam verdes, que o verde já é uma cor nacional. Quanto à saudação o problema é mais grave. Além de uma palavra, ela necessita de um gesto, fáceis ambos, e que se tornem, desde logo, característicos. Plínio solta os seus literatos atrás de um vocábulo. Após muitos estudos, recorre a um termo extremamente nacionalista, como convém ao lema do movimento: Anauê!

O gesto, entretanto é que se afigura de dificil escolha. Comunistas, fascistas e nazistas já tinham se utilizado de todas as gradaçōes de elevação dos braços. Os dedos das mãos estavam todos ocupados pelo punho cerrado de Moscou. Não resta outro remédio, aos integralistas, senão espalmar os dedos bem para cima, numa saudação à lua, ao céu, às nuvens, a qualquer coisa, enfim" (p. 62). E mais adiante: "Quando ia ao Rio de Janeiro, o chefe despachava o seu expediente na salinha da Rua Rodrigo Silva. Contígua a ela, havia uma oficina de alfaiataria, com um gabinete destinado à prova dos clientes. Quando os líderes do integralismo precisavam realizar uma conferência reservada, pediam emprestado ao alfaiate 0 gabinete de provas, que era gentilmente cedido. Esse gabinete era, de alguma forma, uma espécie de 'cervejaria de Munique' dos integralistas. Ali eles confabulavam e organizavam os seus planos mais secretos" (p. 63).

Getúlio Vargas ainda é matéria de três reportagens. Uma delas que marca a abertura do processo eleitoral em 1949 através das declarações de Getúlio a Samuel Wainer, publicadas em 3 de março de 1949 em O Jornal. Os últimos dias do presidente são relatados por Murilo Melo Filho e pela equipe de Manchete resultando numa descrição redundante dos fatos que antecederam o suicídio de Vargas.

Dos textos restantes, dois deles abordam o assassinato do jornalista Nestor Moreira d'A. Noite por forças policiais, enfocando a violência policial $\mathrm{e}$ o estado precário das prisões brasileiras, respectivamente por Darwin Brandão e Edmar Morel. Há ainda o depoimento do General Teixeira Lott relativo aos acontecimentos de novembro de 1955 que depuseram João Café Filho; David Nas- ser desmascarando o deputado Edmundo Barreto Pinto, um produto da política de favoritismo e, finalmente, João Martins registra em 0 Cruzeiro seu testemunho sobre a existência de discos voadores, vistos e fotografados (?) por ele e seu companheiro Ed Keffel, em plena Barra da Tijuca.

Regina Weinfeld Reiss

\footnotetext{
1 Ver artigo de Hélgio Trindade - PI: nic Salgado e a Revolução de 30, Revista Brasileira de Estudos Politicos, número especial, jan. 1974. O autor situa o integralismo entre os movimentos de tendência antiliberal que surgiram a partir de 1930 e a posição de seu lider, Plínio Salgado, frente a Revolução de 30
} 
Sociedade e política no Brasil

Por Soares, Gláucio A.D. São Paulo, Cia. Editora Nacional, 1974.

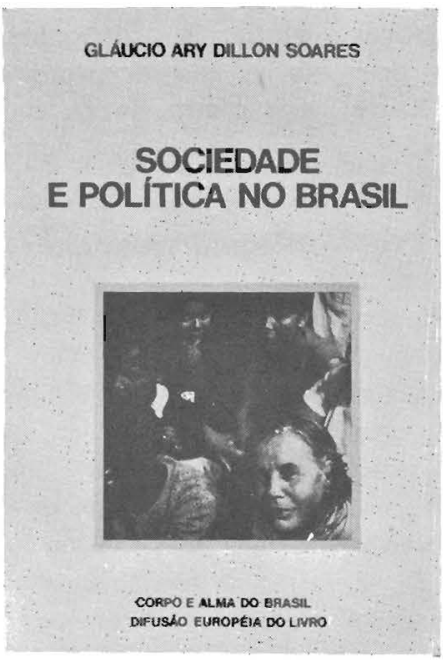

O objeto central do livro é o pro. cesso político brasileiro no período populista que vai de 1945 a 1964. O autor pretende fazer uma análise marxista desse processo, isto é, analisar o processo político hacional como uma superestrutura determinada por uma infra-estrutura socioeconômica. Há um outro aspecto importante dentro do livro, qual seja o de estudar o andamento político atiavés da determinação exercida por processos históricos, amplos, como por exemplo a urbanização e a industrialização cuja conseqüência básica foi a progressiva participação política de grupos e/ou classes sociais até então fora do sistema político.

A parte introdutória do livro é dedicada a uma explanação do papel exercido pelos estados da federação como fulcro de análise

136 do sistema político brasileiro e, portanto, levanta o problema pouco debatido das formas federalistas no Brasil.

O autor oferece uma visão breve do quadro político brasileiro na República Velha através das situações nos planos estadual e municipal. Analisa mais detalhadamente as consequiencias da autonomia financeira municipal e seu reflexo na estrutura de poder. Segundo o autor, a autonomia financeira municipal poderia acarretar o fim do coronelismo, pois
- coronel tinha como base de prestígio local a facilidade de carrear recursos financeiros das esferas estaduais para o município, mas não o fim do sistema oligárquico. Na verdade, a autonomia financeira eliminaria uma necessidade, isto é; a busca de recursos financeiros fora do âmbito municipal.

O sistema oligárquico estadual é mostrado nas suas dissensões internas e seus instrumentos de dominação. A autonomia financeira dos estados decorria do controle que exerciam sobre a exportação ao passo que sua autonomia política, consagrada na Constituição de 1891, era garantida no plano da força, pela manutenção de suas próprias forças armadas. $E$ com vistas a isso recorre a exemplos elucidativos nos diversos momentos e estágios do sistema de dominação oligárquico. O esqueleto da do. minação é o seguinte Empreguismo e nepotismo - colocação de parentes e amigos em posição de poder e prestígio e distribujcão de cargos públicos entre colaboradores políticos; Corrupção eleitoral - recurso corriqueiro na história da República Velha, além de outros.

Em seguida, trata algumas fontes de mudança no esquema oligárquico.

A inserção privilegiada no setor agro-exportador e a conseqüente autonomia financeira propiciaram que alguns poucos estados concentrassem em seu favor - sistema de poder.

Dois marcos alteraram este sisLema político de dominação: no plano político, aquele representado pela Revolução de 30 , ciiação de partidos políticos, ampliação do aparato estatal, etc. No plano socioeconômico, a urbanização e a industrialização.

O autor analisa esses dois últimos fatores como determinantes de uma gradativa mudança socioeconômica já antes dos anos 30. O fenômeno da vibanização é definido pelo. prccesso de migração de elementos das zonas rurais menos favorecidas que passam a se concentrar nas zonas urbanas. Esses processos implicaram uma maior participação po- lítica de novos grupos sociais, em especial a partir da Revolução de 30, com a extensão da cidadania às classes trabalhadoras e a grupos da classe média urbana. Segundo o autor, o que se verifica é um maior poder em termos eleitorais desses novos grupos que surgiram, dando origem a partidos políticos que representavam seus ideais e reivindicações.

Tais fenômenos acarretam a desintegração do sistema oligárquico municipal pois a dominação exercida pelas famílias tradicionais fora minado. Não obstante, subsistem certos elementos conducentes a um sistema político elitizado, que o autor denomina de processo político poliárquico, caracterizado entre outras coisas pelo processo seletivo de escolha, usado pelos partidos políticos, dos candidatos a cargos nas esferas estadual e federal. A fim de fundamentar tal elitização, recorre a pesquisas a respeilo da origem ocupacional dos políticos.

A partir daí, sua preocupação volta-se exclusivamente para o cenário político-partidário brasileiro no período populista. Começa por uma exaustiva exposição da canalização dos novos grupos sociais em termos eleitorais. Após o Estado Novo, havia no Brasil dois partidos nacionais: UDN (União Democrática Nacional) e - PSD (Partido Social Democrático). Tanto a UDN quanto o PSD ancoravam boa parte de seu poder na dominação socioeconômica locat, seja exclusiva de um dos dois ou dividida entre eles. Porém, o quadro partidário é formado de inúmeros pequenos partidos representantes de grupos e/ou frações de classes. Dentre eles, os que mais se destacaram são os partidos de orientação reformista (Partido TrabaIhista Brasileiro, por exemplo) ou esquerdista (Partido Comunista Brasileiro). Assinala o crescimento desses partidos em termos eleitorais durante o período 45-64, em contraposição ao esvaziamento político dos antigos partidos nacionais (UDN, PSD), especialmente o último. Estuda também - posicionamento e potencial eleitoral dos partidos políticos, fazendo comparações entre parti- 
dos reformistas e conservadores para o período. Sobre os partidos apóia-se em dados dos censos eleitorais e sua análise oferece uma ampla visão das mudanças do cenário político-partidário brasileiro no período 45-64.

O autor emprega uma análise de correlação de variáveis socioeconômicas com as variáveis po. líticas tendo como unidades de estudo dois grupos de estado, de um lado, o grupo de estados desenvolvidos e, de outro, os subdesenvolvidos, fazendo comparações entre eles. O objetivo central deste tipo de análise é apresentar uma descrição do impacto das diferenças socioeconômicas desiguais sobre vários aspectos da política brasileira. Segundo o autor, estes dois grupos de estados são: de um lado, os desenvolvidos representados por' São Paulo, Paraná, Santa Catarina, Rio Grande do Sul; de outro, os estados restantes, considerados o grupo subdesenvolvido. O estudo apresenta os pontos mais importantes e elucidativós das diferenças socioeconômicas entre os grupos mencionados. Esses pontos são entre muitos: diferenças regionais per capita; niveis de industrialização; grau de urbanização: índice de alfabetização, quantidade de matrículas universitá rias; e as diferenças da concentração das propriedades agrícolas. Toda a análise é confeccionada por dados quantificados, oferecendo-nos uma idéia global da relação entre o desenvolvimento econômico e social e o quadro político brasileiro no período. Particularmente é a parte mais importante do livro, pois demonstra as consequiências que o desenvolvimento econômico desigual acarreta para o desenvolvimento e a participação do povo no processo político.

Ronaldo Bianchi

\section{A política do desenvolvimento na era de Vargas}

Por John D. Wirth. Rio de Janeiro, Fundação Getulio Vargas, 1973.

John D. Wirth propõe-se a analisar o processo de elaboração das diretrizes políticas básicas tomadas com vista ao desenvolvimento econômico em áreas estratégicas durante a era de Vargas. Desen. volve sua análise através do estudo de três casos particulares: o comércio internacional, a siderur. gia e o petróleo, afirmando a interligação dos três casos e a conlinuidade de atitudes e instituições na era de Vargas.

Dentre os elementos que in. fluenciam o processo decisório temos a ênfase nos grupos de in teresses econômicos privados nacionais, a relação pela qual se ligam formal ou informalmente ao governo e seus vínculos ao estrangeiro. For esse lado, ressalta a dependência econômica e política em relação ao exterior. No caso da siderurgia e do petróleo, o exército com sua ideologia nacional desenvolvimentista, tem um papel importante na elaboração da política. No caso do petróleo, outro fator relevante é a manifestação da classe média através do nacionalismo político.

Vargas vai seguir uma política eminentemente conciliatória, pois sendo favorável tanto a interesses estrangeiros como aos interesses privados nacionais reluta em aceitar uma solução estatal com exclusão dos referidos interesses da mesma. Vejamos como isso se deu em cada caso.

\section{O comércio internacional na década de 30}

O comércio internacional caracteriza a década de 30 , pois a economia nacional está voltada essencialmente para o exterior. A partir de 1934, o Brasil viu-se colocado entre duas potências, cada uma com um sistema econômico, político e ideológico incompatíveis, em luta, para afirmar aqui sua hegemonia. Os Estados Unidos, nação democrática a favor do livre comércio, e a Alemanha desfraldando a bandeira da economia dirigida. Esse conflito também se manifesta internamente. Temos os grupos do café tradicionalmente ligados aos EUA, maior importador do Brasil; por outro lado os grupos do algodão e outros grupos agrários dependentes do comércio com a Alemanha, o qual ciescia em importância.

Ao nível da máquina governamental encontramos a mesma divisão. O Embaixador em Washington, depois Ministro das Relações Exteriores, (1937-44), Oswaldo Aranha, é favorável ao tradicional alinhamento político com os EUA. O Ministro das Relações Exteriores João Carlos Macedo Soares (identificado com interesses ligados ao algodão em São Paulo) é favorável ao comércio com a Alemanha, assim como também outras autoridades do governo.

Outro elemento importante na formulação da política pelo Estado eram os representantes oficiosos que defendendo interesses pessoais serviam como mediadores entre os grupos internos e os interesses estrangeiros; por exemplo Valentım Bouças, importador e intermediário simpático aos EUA, Olavo Egydio de Souza Aranha (paulisıa com interesses no cultivo de algodão, café e na exportaçãc de minério de ferro) ativo promotor dos interesses alemães.

Roberto Simonsen, presidente da Federação das Indústrias do Estado de São Paulo, não conse- 
guiu impor um plano de cunho nacionalista ao comércio internacional, pois os industriais não tinham alcançado ainda um peso político efetivo.

Pressionado pelas duas potências estrangeiras e pelos grupos agrários internos, Vargas procurou manter um equilibrio seguindo assim uma política eclética, tentando obter vantagens econômicas imediatas evitando um alinhamento político explícito. Para coordenar os in* teresses dos grupos internos e, ademais, para fortalecer o seu poder criou o Conselho Federal do Comércio Exterior. Esse mesmo mostrou-se mais eficaz como "caixa de ressonância e órgão legitimador" dos diversos grupos agro-exportadores do que como formulador da política comercial. Assim a política comercial de Vargas limitou-se à diversificação e ampliação de mercados.

\section{A siderurgia 0 Estado Novo}

O ponto de vista de que uma siderurgia só poderia ser estabelecida com a ajuda do capital es. trangeiro e o de que não deveria depender deste capital são os dois pólos de referência da política siderúrgica. No processo decisório - Exército desempenhou papel importante e ativo, orientado pelo nacionalismo econômico. O projeto da Usina Siderúrgica de Volta Redonda, em 1940, representou um compromisso entre os dois pontos de vista.

A inviabilidade econômica interna era um dos principais em. pecilhos para a construção de uma usina siderúrgica, pois apesar da abundância de minério de ferro o carväo nacional era ruim. - sistema ferroviário precário e as possibilidades de financiamen. to interno insuficientes. Ademais, os interesses financeiros dos países desenvolvidos ligados ao aço não estavam empenhados em in. vestir nos paises subdesenvolvidos entre 1910 e 1937.

Em 1920, apresenta-se o único projeto viável idealizado pelo americano Percival Farquhar: o contrato de Itabira. Em torno desse contrato vai girar toda a questão politica referente ao pro- blema siderúrgico, opondo-se desde logo várias correntes nacionalistas. Na década de 30, Farquhar continua lutando, mas falha por dificuldades financeiras. $V$ á $r$ ios grupos privados nacionais também se propốem a construir uma usina siderúrgica, que por exigir vultosos financiamentos do Estado continua inviável do ponto de vista econômico. Com a implantaçäo do Estado Novo o Exército chega à conclusão de que a solução deve ser de âmbito nacional sob o controle estatal.

No final da década de 30 surgem interesses, tanto da Alemanha como dos EUA, para investir no Brasil. Grupos privados, Va. lentim Bouças, o Ministro das Relaçōes Exteriores Oswaldo Aranha e o próprio Vargas são a favor dos EUA. O Exército e os nacionalistas apoiados pelo Ministro dos Transportes, General Mendonça Lima, tendo em vista umá solução estatal mostraram-se mais inclinados pela Alemanha. Por fim, Vargas entrega o problema siderúrgico ao Conselho Técnico de Economia e Finanças, ligado à iniciativa privada e aos EUA; e depois do Conselho Federal de Comércio Exterior, "biombo" administrativo para o Exército. No entanto, nenhum desses órgãos apresenta propostas viáveis.

Devido à rivalidade crescente entre os EUA e a Alemanha $\circ$ poder de Barganha do Brasil aumenta. Com a pressão de Vargas a United States Steel Corporation parece disposta a investir no Brasil, apresentando um plano economicamente viável, que recebe o apoio de Vargas a despeito da oposiçăo dos nacionalistas, mas a United States Steel Corporation desiste. Enquanto isso, os elementos necessários para a viabilidade econômica interna haviam surgido. Vargas exigindo uma decisäo dos EUA consegue um financiamento que vai permitir a construção de uma usina de aço esıatal de maiores dimensōes.

Desenvolve-se então o projeto da usina siderúrgica de Volta Redonda, símbolo da política conciliatória e modernizadora de Vargas. O projeto conseguiu, com a formação de uma empresa de capital misto, satisfazer os interesses nacionais privados e os militares por ser uma solução nacional e por possibilitar e autosuficiência em matéria de aço.

\section{O petróleo e o segundo governo de Vargas}

A exigência popular militar quanto a necessidade de uma solução estritamente estatal para a questão do petróleo é que vai deter. minar a fundação da Petrobrás em 1953. E apesar do fortalecimento do Estado, vai-se evidenciar a superação da política conciliatória de Vargas.

A questão do petróleo divide-se em três frases. A primeira desenvolve-se durante o Estado Novo e se caracteriza pela legislação nacionalista precoce feita pelo Exército através do General Horta Barbosa, presidente do ConseIho Nacional do Petróleo. Tal legislação foi possivel devido à falta de interesse por parte das empresas petrolíferas estrangeiras em investir no Brasil e à fraqueza econômica dos grupos nacionais privados. $\mathrm{Em} \mathrm{1958,} \mathrm{a} \mathrm{indús-}$ tria do petróleo é colocada diretamente sob o controle do CNP, que limitou a participação do capital estrangeiro e instaurou um controle maior sobre os interesses regionais e privados.

Horta Barbosa enfrenta a oposição da maioria dos ministros, de grupos nacionais e estrangeiros, do Departamento Administrativo do Serviço Público. Lentamente perde a iniciativa politica restando-lhe o poder de veto que uriliza contra empresas estrangeiras.

Horta renuncia em 1943 e é substituido pelo Coronel João Carlos Barreto, favorável à iniciativa privada e ao capital estrangeiro. Vários projetos privados com ajuda do capital estrangeiro são apresentados e alguns até se realizam sem que, no entanto, cheguem a formular uma alternativa para uma empresa governamental. Em outubro de 1947 é apresentado $\circ$ Estatuto do $\mathrm{Pe}$ tróleo, que por sua vez näo satisfaz, nem as empresas estrangeiras, nem os nacionalistas. Em torno do Estatuto vai-se desenca- 
dear um debate público generalizado e de âmbito nacional. Em abril de 1948 é fundado o Centro de Estudos e Defesa do Petróleo como órgão dos nacionalistas em favor do monopólio estatal do petróleo, com o apoio das classes médias. Assim, em fins de 1948, O Estatuto está politicamente morto. No desejo de se fortalecer o Departamento de Administração do Serviço Público propõe um projeto mais próximo da solução estatal. Os grupos privados agem por iniciativa própria, Dutra contemporiza, o que vai redundar apenas em soluções parciais.

Em 1951, torna-se necessário uma ação do governo. Após várias tentativas infrutiferas de atrair o capital estrangeiro Vargas decide-se pela solução estatal. Encomenda um projeto altamente tecnocrático, visando sua tradicional polit i c a conciliatória, abrindo uma brecha ao capital estrangeiro e permitindo um acesso à diretoria por parte dos grupos privados. $O$ projeto, no entanto, recebe oposição de todos os setores não sendo mais aceita a indefinição de Vargas. Os principais focos de oposição são os jornais, os nacionalistas da Câmara, o Clube Militar, do Centro de Estudos e Defesa do Petróleo. O governo com maioria no Congresso ainda permanece tranquiilo. Com a apresentação de um projeto alternativo pelo PTB e a discussão do projeto de Vargas durante a campanha eleitoral para a presidência do Clube Militar, a política de Vargas cai ainda mais em descrédito. Em oposição a Vargas, e também por oportunismo, a UDN propõe um terceiro projeto, favorecendo o monopólio estatal total. Após uma série de emendas (exclusão do capital estrangeiro e dos interesses privados da diretoria), mantendose no entanto seu orçamento financeiro, Vargas consegue o apoio dos grupos nacionalistas. Somente a UDN e o Centro de Estudos de Defesa do Petróleo permaneceram na oposição. O Senado, representante dos interesses privados, tentou em vão fazer emendas. A Petrobrás foi aprovada em 3 de outubro de 1953. No entan- to, o projeto já não era o que Vargas idealizara.

Em suma, a ênfase da análise de Wirth recai sobre a tentativa de mostrar a participação e poder relativo dos vários elementos no processo decisório, a saber: grupos de interesses nacionais e estrangeiros, personalidades, ministros e conselhos administrativos, 0 Exército, a classe média, o poder presidencial. Res. salta igualmente a influência da ideologia no processo decisório, assim como o nacionalismo econômico e popular. Ao mesmo tempo, mostra que as possibilidades de se chegar aos objetivos alcançados dependem da viabilidade destes e da dependência política ao exterior. O principal objetivo de Wirth é mostrar através destes três exemplos o crescente fortalecimento do Estado e "o crescente controle interno do processo da elaboração da política do governo".

Rudolf Caio Petersen
Lista das publicações recebidas até 22 de junho de 1974

\section{LIVROS:}

Fernandes, Florestan. Comunidade e sociedade. São Paulo, Companhia Editora Nacional, 1973.

George, Pierre. Panorama do. mundo atual. São Paulo, Difusão Eurcpéia do Livro, 1974.

Goldmann, Lucian. Ciências humanas e filosofia: que é a sociologia? São Paulo, Difusão Européia do Livro, 1974.

Grau, Eros Roberto. Regiōes metropolitanas. São Paulo, José Buchatsky ed., 1974.

Janes, Manley Howe. Tomada de decisōes pelo executivo. São Paulo, Editora Atlas.

Lacerda, Carlos et alii. Reportagens que abalaram o Brasil. Rio de Janeiro, Bloch Editores.

Lacoste, Yves. Os países subdesenvolvidos. São Paulo, Difusão Européia do Livro.

Motta, Fernando C. Prestes. Teoria geral da administração. São Paulo, Livraria Pioneira Editora, 1974. 
Pereira, Luiz Carlos Bresser. Empresários administradores no Brasil. São Paulo, Editora Brasiliense, 1974.

Soares, Gláucio Ary Dillon. Socie dade política no Brasil. São Paulo, Cia. Editora Nacional, 1974.

\section{PERIÓDICOS}

Atualidades Sanbra, São Paulo, Sociedade Algodoeira do Nordeste Brasileiro S. A.

Bibliografia Universitária, Obras de nivel superior, São Paulo, Cia. Editora Nacional.

Boletim Mensal, São Paulo, Ministério da Fazenda, Banco Central do Brasil, Assessoria Técnica Conjunta.

Brasília: Bibliografias-3, Brasília, Câmara dos Deputados, Diretoria Legislativa, Centro de Documentação e Informação, Coordenação de Publicações.

Cadernos DCP, Departamento de Ciência Política da Universidade Federal de Minas Gerais, Belo Horizonte, mar. 1974.

Guia de Incentivos Fiscais, Federação do Comércio do Estado de Minas Gerais, Belo Horizonte, MG.

The Journal of Peasant Studies, Frank Cass \& Co., London.

Mercado de Trabalho, Ministério do Trabalho e Previdência Social, Rio de Janeiro.

Fundação JP, Fundação João $\mathrm{Pi}$ nheiro, Belo Horizonte, MG.

Stanford Lectures in Accounting 1973, Graduate School of Business, Stanford University.

Statistiques \& Etudes Financières, Ministère de l'Economie et des Finances, Bureau des Relations Extérieures et des Publications, France.

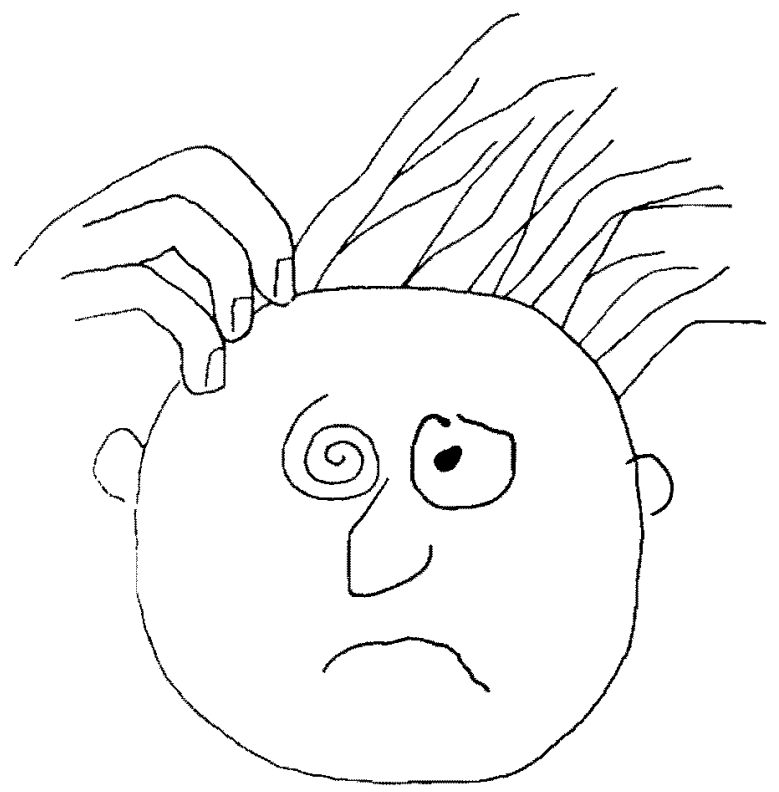

recorra a Curriculum

já se foi o tempo em que o professor do ensino médio não tinha a quem recorrer

hoje, existe a revista Curriculum que pensa sempre nos problemas do professor

e o ajuda a resolvê-los

estudantes da faculdade de filosofia, orientadores educacionais

e orientadores pedagógicos só tem a ganhar lendo Curriculum.

Curriculum,

a única revista sobre ensino médio editada no Brasil

Assinaturas: Editora da Fundação Getulio Vargas - Praia de Botafogo, 188 - CP 21120 - ZC.05 